\title{
Syntheses of 6-Deoxyhex-5-enopyranosides from 6-Bromo-6-deoxy- or 6- $O$ - $p$-Tolylsulfonylhexopyranosides by the Use of DBU in DMSO
}

\author{
Ken-ichi Sato, ${ }^{*}$ Noriyuki Kubo, Ritsuko TaKada, and Shogo Sakuma \\ Laboratory of Organic Chemistry, Faculty of Engineering, Kanagawa University, \\ Rokkakubashi, Kanagawa-ku, Yokohama 221
}

(Received July 30, 1992)

\begin{abstract}
Various kinds of nonbranched and methyl-branched 6-deoxyhex-5-enopyranoside derivatives were prepared from 6-bromo-6-deoxy or 6- $Q$ - $p$-tolylsulfonylhexopyranoside in a one-pot procedure by a successive treatment with iodide anion and 1,8-diazabicyclo[5.4.0]undec-7-ene in dimethyl sulfoxide. The scope and limitations of this reaction have become apparent by observing the reactions of 18 substrates. The yields of altropyranoside and 2-deoxyribo-hexopyranoside derivatives were high, except for the 2,3-anhydropyranoside derivative. Methylbranched 6-deoxyhex-5-enopyranoside derivatives were also obtained in practical yields.
\end{abstract}

6-Deoxyhex-5-enopyranosides are very useful precursors in biologically important natural-product synthesis, such as 6-deoxy-L-hexose ${ }^{1)}$ and the cyclitol derivative. $^{2)}$ In general, 6-deoxyhex-5-enopyranosides have been synthesized by treating the corresponding 6-bromo derivative with $\mathrm{AgF} /$ pyridine, ${ }^{3)}$ 1,8-diazabicyclo[5.4.0]undec-7-ene (DBU) $/ \mathrm{CH}_{3} \mathrm{CN}^{4)}$ or $\mathrm{NaH} / \mathrm{N}, \mathrm{N}$ dimethylformamide (DMF). ${ }^{5)}$ These methods, however, have some limitations, such as displacement reactions with fluorine, acyl migration reaction, and deacylation. At the beginning of our 5-enopyranosides syntheses, we used DBU/ $\mathrm{CH}_{3} \mathrm{CN}$ as a useful synthetic method; however, it required a longer reaction time and gave side products in many cases. Furthermore, this method did not work well in the case of methyl-branched series. Regarding another type of elimination reaction, $\mathrm{S}$. Hannesian has reported on the use of DBU/DMSO in the synthesis of carbohydrate derivatives containing the vinylic thioether group by eliminating the mesyl group. In that report, the elimination with $\mathrm{DBU} / \mathrm{DMSO}$ under heating for $2.5 \mathrm{~h}$ at $85^{\circ} \mathrm{C}$ gave the corresponding 2,3unsaturated derivative in good yield. ${ }^{6)}$ The strong base ability of DBU/DMSO probably suggests the intermediacy of the DMSO carbo anion in DMSO. If we can use DBU/DMSO methods in the syntheses of hex-5enopyranosides, the elimination reaction may progress faster than $\mathrm{DBU} / \mathrm{CH}_{3} \mathrm{CN}$. In order to contribute to the development of such 6-deoxyhex-5-enopyranosides syntheses, the authors examined DBU/DMSO methods and communicated a convenient and general method for synthesizing 6-deoxyhex-5-enopyranosides from the corresponding 6-bromo-6-deoxy- or 6- 0 -p-tolylsulfonylhexopyranosides in a one-pot procedure by a successive treatment with the iodide anion, DBU, and molecular sieves (MS) 4A in dimethyl sulfoxide (DMSO), instead of $\mathrm{CH}_{3} \mathrm{CN}$. This paper describes details concerning the communication $^{7)}$ as well as the scope and limitations of the above method by using 18 substrates, i.e., nonbranched $(1,5,8,12,14,16,18,20,22,25$, and 28) and a methyl-branched series $(32,34,36,38,40,42$, and 44) (Chart 1, Figs. 1 and 2).

\section{Results and Discussion}

Concerning the elimination reaction of the 6-bromo-6deoxy- or 6- $Q$-p-tolylsulfonylhexopyranoside derivative, conditions (A): DBU/DMSO, $80-110^{\circ} \mathrm{C}$, were selected as preliminary experiments in order to determine the influence of steric factors, functional groups, and protecting groups in this elimination reaction. At first, the gluco series was examined under conditions (A). After methyl 4- $O$-benzoyl-6-bromo-6-deoxy-2,3-di- $O$-methyl- $\alpha$-D-glucopyranoside (1) was treated with 1.2 equiv $\mathrm{DBU}$ in $\mathrm{DMSO}$ at $110^{\circ} \mathrm{C}$ (until the starting material disappeared on TLC), the mixture was poured into water and extracted with ethyl acetate to give the desired methyl 4-O-benzoyl-6-deoxy-2,3-di- $O$-methyl- $\alpha$-D- $x y l o-$ hex-5-enopyranoside (2), as well as unexpected by-products methyl 4,6-di- $O$-benzoyl-2,3-di- $O$-methyl- $\alpha$-D-glucopyranoside (3) and methyl 6- $O$-benzoyl-2,3-di- $O$-methyl- $\alpha$-D-glucopyranoside (4) in 32,28 , and $9 \%$ yields, respectively. The NMR data of compound 2 showed a disappearance of the $\mathrm{H}-5$ proton and the appearance of methylene protons. Compound 3 showed low-field shifts of the $\mathrm{H}-6$ and $\mathrm{H}-6^{\prime}$ protons and 10 protons for two benzoyl groups. Compound 4 showed 5 protons for the benzoyl group, a high-field shift of the H-4 proton, and a low-field shift of the H-6 and H-6 protons. In a similar manner as mentioned above, methyl 4- $O$-benzyl-2,3-di- $O$-methyl-6- $O$ - $p$-tolylsulfonyl- $\alpha$-D-glucopyranoside (5) gave the desired methyl 4- $O$-benzyl-6-deoxy-2, 3 -di- $O$-methyl- $\alpha$-D-xylo-hex-5-enopyranoside (6) as well as a 6-hydroxy by-product, methyl 4-O-benzyl-2,3-di- $O$ methyl- $\alpha$-D-glucopyranoside (7) in 28 and $38 \%$ yields,

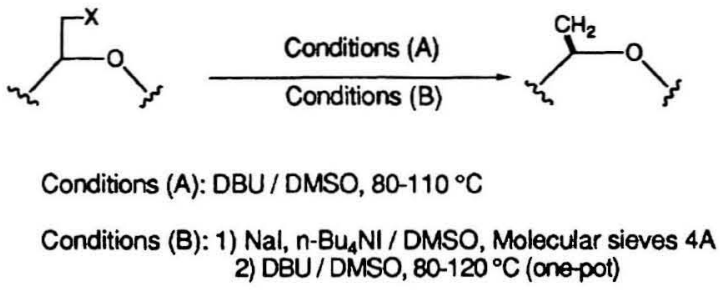

Chart 1. 


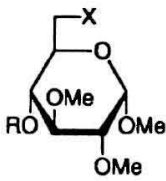

$1 \mathrm{R}-\mathrm{Bz} X=\mathrm{Br}$ $3 \mathrm{R}=\mathrm{Bz} X=\mathrm{OBz}$

$4 \mathrm{R}=\mathrm{H} \quad X=\mathrm{OBz}$

5 $R=B n X=O T s$

$7 \mathrm{~B}=\mathrm{Bn} \mathrm{X}=\mathrm{OH}$

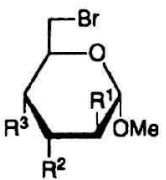

$14 R^{1}=R^{3}=O B z \quad R^{2}=O A C$

$18 R^{1}=N_{3} R^{2}=O A C R^{3}=O B$

$17 R^{1}=O A C R^{2}=N H A C R^{3}=O B z$ $19 R^{1}=N_{3} R^{2}=O A C R^{3}=O B z$

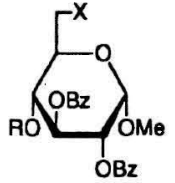

$8 R=A C X=O T s$

$10 \mathrm{R}=\mathrm{AC} \quad X=\mathrm{OBz}$

$11 R=A C \quad X=O A C$

9 $A^{1}=R^{2}=B z \quad R^{3}=A C$

12 R=H $X=O T s$

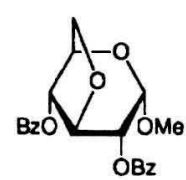

13

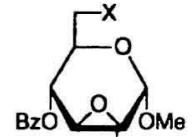

$25 \mathrm{X}=\mathrm{Br}$ $27 \mathrm{X}=\mathrm{OBz}$

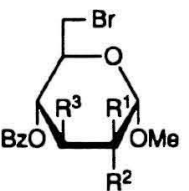

$32 R^{1}=M_{\theta} R^{2}=R^{3}=O A C$ $34 R^{1}=R^{3}=O A C R^{2}=M \theta$ $36 R^{1}=M e R^{2}=R^{3}=O M \theta$ $38 R^{1}=R^{3}=O M \theta R^{2}=M \theta$

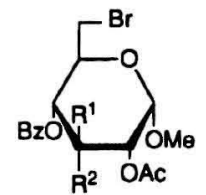

$40 R^{1}=M \theta R^{2}=O A C$

$42 R^{\prime}=O A C R^{2}=M \theta$

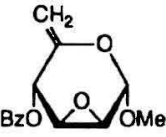

26

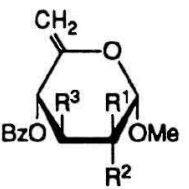

$33 R^{1}=M \theta R^{2}=R^{3}=O A C$ $35 R^{1}=R^{3}=O A C R^{2}=M \theta$ $37 R^{1}=M_{\theta} R^{2}=R^{3}=O M \theta$ $39 R^{1}=R^{3}=O M e R^{2}=M \theta$

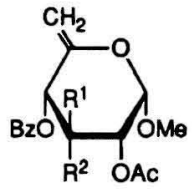

$41 R^{1}=M_{\theta} R^{2}=O A C$ $43 R^{1}=O A C R^{2}=M e$

Fig. 1.<smiles>[X]C1C2OC3OC1C(O3)C2O</smiles>

$28 \mathrm{R}=\mathrm{Bz} \cdot \mathrm{X}=\mathrm{Br}$ $30 \mathrm{R}=\mathrm{Bz} \quad \mathrm{X}=\mathrm{OBz}$ $31 \mathrm{R}=\mathrm{H} \quad \mathrm{X}=\mathrm{OBz}$

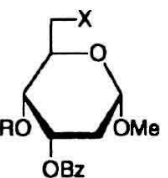

$20 \quad \mathrm{R}=\mathrm{Bz} \quad \mathrm{X}=\mathrm{Br}$ $22 \quad \mathrm{R}=\mathrm{Me} X=\mathrm{Br}$ $24 \mathrm{R}=\mathrm{Me} X=\mathrm{OB}$

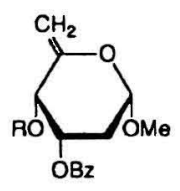

$21 R=B z$

$23 \mathrm{R}=\mathrm{Me}$

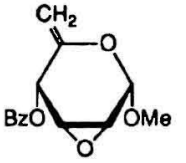

29

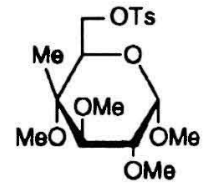

44

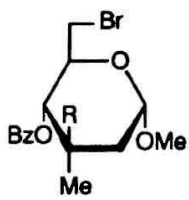

$46 \mathrm{R}=\mathrm{OH}$ $48 \mathrm{R}=\mathrm{NHAC}$

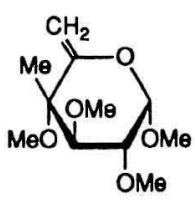

45

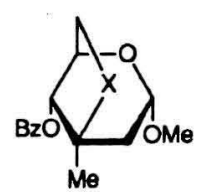

$47 X=0$

$49 X=N A C$

Fig. 2.

respectively. The structure of 7 was supported by a direct comparison with a known compound or the precursor of compound 5. Under similar conditions, methyl 4- $O$-acetyl-2,3-di- $O$-benzoyl-6- $O$ - $p$-tolylsulfonyl- $\alpha$-Dglucopyranoside (8) gave the desired methyl 4-O-acetyl2,3-di- $O$-benzoyl-6-deoxy- $\alpha$-D-xylo-hex-5-enopyranoside
(9) as well as by-products methyl 4-O-acetyl-2,3,6-tri- $O$ benzoyl- $\alpha$-D-glucopyranoside (10) and methyl 4,6-di- $O$ acetyl-2,3-di- $O$-benzoyl- $\alpha$-D-glucopyranoside (11) in 10, 22 , and $20 \%$ yields, respectively. Compound 10 showed 15 protons for three benzoyl groups and 3 protons for an acetyl group in its NMR data. The other compound 
11 showed 10 protons for two benzoyl groups and 6 protons for two acetyl groups. However, it was not easy to determine the structures of compounds $\mathbf{1 0}$ and $\mathbf{1 1}$, respectively (especially, the position of the acetyl and benzoyl groups concerned with acyl migration), since the chemical shift of each ring proton is very similar to each other. Therefore, in the determination of the above-mentioned structures compound $\mathbf{1 0}$ was directly compared with that obtained by acetylation of methyl 2,3,6-tri- $O$-benzoyl- $\alpha$-D-glucopyranoside. ${ }^{8)}$ The structure of compound $\mathbf{1 1}$ was determined by a comparison of the physical constants which were derived by acetylation of methyl 2,3-di- $O$-benzoyl- $\alpha$-D-glucopyranoside. Treatment of methyl 2,3-di- $O$-benzoyl-6- $O$-tolylsulfonyl$\alpha$-D-glucopyranoside $(\mathbf{1 2})$ at $80^{\circ} \mathrm{C}$ for $7.5 \mathrm{~h}$ gave the bicyclic compound, methyl 3,6-anhydro-2,4-di- $O$-benzoyl$\alpha$-D-glucopyranoside (13), in $86 \%$ yield. The structure of 13 was supported by IR (no hydroxyl group), the lowfield shift of the H-4 proton and the high-field shift of the $\mathrm{H}-3$ proton in the NMR spectrum, indicating benzoyl migration. Furthermore, the conformational change due to the formation of an anhydro ring between C-3 and C- 6 was supported by the changed chemical shifts (H-3: ca $1.0 \mathrm{ppm}$ high field shift and $\mathrm{H}-4$ : ca $1.0 \mathrm{ppm}$ low field shift) and coupling constants $\left(J_{1,2}=3.8\right.$ to 3.4 $\mathrm{Hz}, J_{2,3}=9.6$ to $4.6 \mathrm{~Hz}, J_{3,4}=9.6$ to $5.2 \mathrm{~Hz}$ ).

Similarly, elimination reactions of altro-, 2-deoxyribo-, and 2,3-anhydro compounds were carried out under conditions (A). In the case of the altro series $(14,16$, and 18), reactions were carried out as follows. Methyl 3- $O$-acetyl-2,4-di- $O$ - benzoyl-6-bromo-6-deoxy- $\alpha$-Daltropyranoside 14, methyl 3-acetamido-2- $O$-acetyl-4O-benzoyl-6-bromo-3,6-dideoxy- $\alpha$-D-altropyranoside 16, and methyl 3-O-acetyl-2-azido-4-O-benzoyl-6-bromo-2,6dideoxy- $\alpha$-D-altropyranoside 18 were treated with $\mathrm{DBU}$ in DMSO at $80^{\circ} \mathrm{C}$ for $2 \mathrm{~h}$ to give the corresponding desired 6-deoxyhex-5-enopyranosides, methyl 3- $O$-acetyl2,4-di- $O$-benzoyl-6-deoxy- $\alpha$-D-arabino-hex-5-enopyranoside (15), methyl 3-acetamido-2- $O$-acetyl-4- $O$-benzoyl3,6 -dideoxy- $\alpha$-D-arabino-hex-5-enopyranoside (17), and methyl 3- $O$-acetyl-2-azido-4- $O$-benzoyl-2,6-dideoxy- $\alpha$ D-arabino-hex-5-enopyranoside (19) in 78,80 , and $82 \%$ yields, respectively.

In the case of the 2-deoxyribo series (20 and 22), the reactions were carried as follows. Methyl 3,4-di- $O$-benzoyl-6-bromo-2,6-dideoxy- $\alpha$-D-ribo-hexopyranoside 20 was treated at $80^{\circ} \mathrm{C}$ for $2 \mathrm{~h}$ to give the desired methyl 3 , 4-di- $O$-benzoyl-2,6-dideoxy- $\alpha$-D-erythro-hex-5-enopyranoside $(\mathbf{2 1})^{3)}$ in $92 \%$ yield. In a similar manner as mentioned above, methyl 3- $O$-benzoyl-6-bromo-2,6-dideoxy4- $O$-methyl- $\alpha$-D-ribo-hexopyranoside (22) was treated at a slightly higher temperature $\left(100^{\circ} \mathrm{C}, 3 \mathrm{~h}\right)$ to give the desired methyl 3-O-benzoyl-2,6-dideoxy-4- $O$-methyl- $\alpha$ D- erythro-hex-5-enopyranoside (23) and a by-product, methyl 3,6-di- $O$-benzoyl-2-deoxy-4- $O$-methyl- $\alpha$-D-ribohexopyranoside (24), in 54 and $18 \%$ yields, respectively. In these ribo series, the yield of the desired hex-5-eno- pyranoside was affected by the protecting group at the C-4-hydroxyl group (ester or ether). Similar evidence for a decreased yield of the $\beta$-elimination product was also observed between the 4- $O$-benzoyl derivative 20 and its 4- $O$-benzyl derivative with $\mathrm{AgF} /$ pyridine. The treatment of the compound $\mathbf{2 0}$ with $\mathrm{AgF} /$ pyridine gave the corresponding hex-5-enopyranoside 21 in $92 \%$ yield; a similar treatment of the 4 - $O$-benzyl derivative of 20 gave the corresponding hex-5-enopyranoside and 6-fluoro derivative in a ratio of $2: 3$ in almost quantitative yield. ${ }^{9)}$ The above results can be explained in terms of the electronic density at $\mathrm{C}-5$, which is induced by the $\mathrm{C}-4-\mathrm{OH}$ protecting group.

In the case of 2,3-epoxide derivatives ( 25 and 28 ), reactions were carried out as follows. Methyl 2,3-anhydro4- $O$-benzoyl-6-bromo-6-deoxy- $\alpha$-D-mannopyranoside 25 was treated at $80^{\circ} \mathrm{C}$ for $20 \mathrm{~h}$ to give the desired methyl 2,3-anhydro-4- $O$-benzoyl-6-deoxy- $\alpha$-D-lyxo-hex-5-enopyranoside (26) as well as an acyl-migrated by-product, methyl 2,3-anhydro-4,6-di- $O$-benzoyl- $\alpha$-D-mannopyranoside (27) in 27 and $16 \%$ yields, respectively. In a similar manner to that mentioned above, methyl 2,3-anhydro-4- $O$-benzoyl-6-bromo-6-deoxy- $\alpha$-D-allopyranoside (28) gave the desired methyl 2,3-anhydro-4- $O$-benzoyl6-deoxy- $\alpha$-D-ribo-hex-5-enopyranoside (29) as well as by-products, methyl 2,3-anhydro-4,6-di- $O$-benzoyl- $\alpha$-Dallopyranoside (30) and methyl 2,3-anhydro-6- $O$-benzoyl- $\alpha$-D-allopyranoside (31) in 13,18 , and $7 \%$ yields, respectively. The structure of the compound $\mathbf{3 1}$ was supported by NMR ( 5 protons for a benzoyl group and the low field shift of H-6 and H-6 ${ }^{\prime}$ protons accompanied by a high-field shift of $\mathrm{H}-4$ proton) and IR ( $\nu_{\mathrm{OH}} 3490$ $\mathrm{cm}^{-1}$ ) (Fig. 1).

As a result, the yields of the required 6-deoxyhex5 -enopyranosides under conditions (A) were generally low (except for the altro series), and accompanied by side reactions, such as hydroxylation at C-6, acyl migration, and 3,6-anhydro ring formation. The resulting relatively high yields and selective formation of 6-deoxyhex-5-enopyranosides in the altro series (14 and 16) can be explained by stereochemically favored conformations of the produced hex-5-enopyranosides, since it is easy to avoid the $A^{1,3}$ strain (between the exo methylene and the benzoyl group at $\mathrm{C}-4$ ) by a conformational change which could be caused by C-2,3, both axial substituent effects. In this DBU method, the most important factor to reduce the yield of the required 6-deoxyhex-5-enopyranoside seems to be the presence of a free hydroxyl group in the substrate. For example, the presence of a hydroxyl group in compound $\mathbf{1 2}$ caused an acyl migration, followed by 3,6-anhydro ring formation by neighboring group participation (stereochemically favored). (Scheme 1) In most cases under conditions (A), acyl migration occurs to give the corresponding 6-O-acyl derivatives. These results indicate that one of the reasons for an enhanced yield of the 6-deoxyhex-5-enopyranoside involves hydroxylation at the C-6 position as 


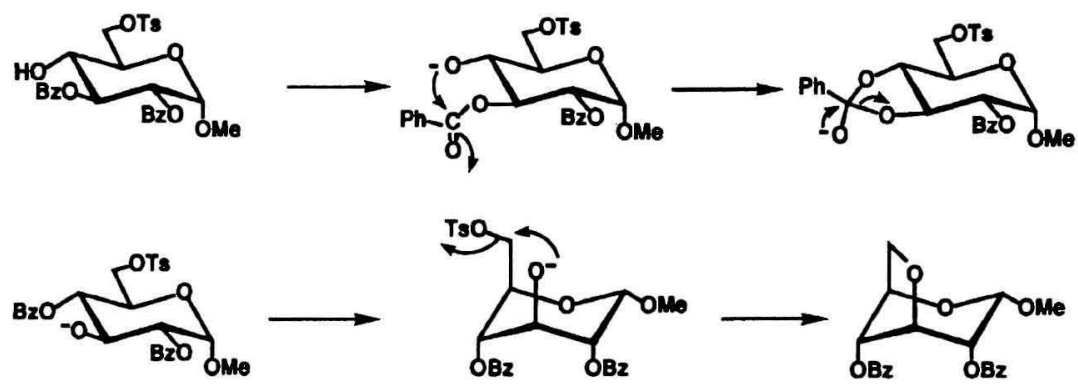

Scheme 1 .

the first step. In the case of compound 8 (4- $O$-acetyl derivative of 12), although 3,6-anhydro ring formation is prevented by acetylation of $\mathrm{C}-4-\mathrm{OH}$, intermolecular migrations of both the acetyl and benzoyl group occur in preference to 3,6-anhydro ring formation. Judging from the above results, it seem possible to prevent hydroxylation as well as the following acyl migration reactions if the progress of the $\beta$-elimination reaction can be controlled under milder conditions. From this point of view, we changed the 6 -bromo or 6 - $O$-tolylsulfonyl derivatives to the 6 -iodo derivative prior to the $\beta$-elimination reaction as follows: $\mathrm{NaI}, n-\mathrm{Bu}_{4} \mathrm{NI} / \mathrm{DMSO}$, then $\mathrm{DBU} / \mathrm{DMSO}$ at $80-110^{\circ} \mathrm{C}$ (iodonation at $\mathrm{C}-6$ position and elimination in one-pot reaction). In most cases, although some increased yields of 6-deoxyhex-5-enopyranosides were observed, these conditions did not give dramatic results. Finally, we proposed the following practical conditions (B) in order to predominantly obtain the desired $\beta$-elimination product. Conditions (B) were carried out in a similar manner as conditions (A), as follows: $\mathrm{NaI}, n-\mathrm{Bu}_{4} \mathrm{NI} / \mathrm{DMSO}$ and molecular sieves $4 \mathrm{~A}$, then DBU/DMSO at $80-110^{\circ} \mathrm{C}$ (6-iodonation and elimination in one-pot reaction). Molecular sieves $4 \mathrm{~A}$ were considered to prevent the hydroxylation reaction at the C-6 position. The optimized conditions for conditions (B) were as follows: A mixture of 6-bromo-6-deoxy or 6-O-p-tolylsulfonylhexopyranoside, $\mathrm{NaI}, n$ - $\mathrm{Bu}_{4} \mathrm{NI}$, and molecular sieves $4 \mathrm{~A}$ in DMSO, was stirred at $80-$ $110^{\circ} \mathrm{C}$ until the starting hexose disappeared on TLC. After the addition of $\mathrm{DBU}$, the mixture was stirred at $80-110^{\circ} \mathrm{C}$ until the intermediary 6 -iodide derivative disappeared. Under these conditions (B), compounds $(1,5,8,14,16,18,20$, and 22$)$ were examined in order to compare the yields of hex-5-enopyranoside that were obtained under conditions (A). The yields of hex5-enopyranosides under conditions (A) were $28-92 \%$, and (B) were $84-95 \%$. (Table 1) Even if under conditions (B), the acyl migration reactions of 2,3-anhydro compounds $\mathbf{2 5}$ and $\mathbf{2 8}$ could not be prevented. It might be necessary to consider other types of the acyl migration as shown in Scheme 2. Since such compounds as $\mathbf{2 5}$ and $\mathbf{2 8}$ may have unfavorable steric factors to produce the corresponding hex-5-enopyranosides, it is difficult to avoid the $A^{1,3}$ strain by the rigid bicyclic structure.

In our previous studies concerning the syntheses of branched-chain 6-deoxyhex-5-enopyranosides, both the application of $\mathrm{AgF} /$ pyridine and $\mathrm{DBU} /$ benzene or toluene to the corresponding 6-bromo derivatives gave unsuccessful results (no reaction). In order to determine the limitation of this method (conditions B), further applications to methyl-branched sugar series $(\mathbf{3 2}, \mathbf{3 4}, \mathbf{3 6}$, 38, 40, 42, and 44) were examined (Fig. 2). Under conditions (B), methyl 6-bromo-6-deoxy- $\alpha$-D-hexopyranosides 32, 34, 36, 38, 40, and 42 and $6-O-p$-tolylsulfonyl- $\alpha$-D-hexopyranoside 44 could also be converted into the corresponding 6-deoxyhex-5-enopyranosides (33, $35,37,39,41,43$, and 45) in good yields (Table 2). Judging from the above results, conditions (B) seems to provide a general method for preparing hex-5-enopyranoside in a one-pot reaction. However, it must be noted that the final problems of this reaction are acyl migration and the participation of neighbors. A few instances of neighbor participation, as observed in compound 12, have also been reported by H. Kodama ${ }^{10}$ ) and M. Matsuzawa, ${ }^{11)}$ respectively, in the elimination reaction of the compound (46 and 48 ). The elimination reactions of compound 46 with $\mathrm{AgF}$ /pyridine at room temperature for $3 \mathrm{~h}$ and compound 48 with DBU/benzene under reflux condition for $2 \mathrm{~h}$ gave the corresponding bicyclic 3,6-anhydro derivative (47) ${ }^{11)}$ and 3,6-acetylepimino derivative $(49)^{11)}$ in 82 and $83 \%$ yields, respectively. In conclusion, it is necessary to consider the steric factor, protecting group, and neighboring participation in order to obtain the corresponding 6-deoxyhex5 -enopyranoside in good yield.

\section{Experimental}

All melting points were uncorrected. The solutions were evaporated under reduced pressure at a bath temperature not exceeding $40^{\circ} \mathrm{C}$. The optical rotations were measured in a $0.5 \mathrm{dm}$ tube with a JASCO DIP-140 polarimeter in chloroform. ${ }^{1} \mathrm{H}$ NMR spectra were recorded in chloroform$d$ with a JEOL FX-200 spectrometer. The chemical shifts, coupling constants, and IR frequencies were recorded in $\delta$, $\mathrm{Hz}$, and $\mathrm{cm}^{-1}$ units, respectively.

General Procedures. Conditions (A): A stirring mixture of substrate $(0.5 \mathrm{mmol})$ and 1,8-diazabicyclo[5.4.0] undec-7-ene (DBU, $0.6 \mathrm{mmol}$ ) in dry dimethyl sulfoxide (DMSO, $6.0 \mathrm{~cm}^{3}$ ) was heated under argon at $80-110^{\circ} \mathrm{C}$ until the starting compound disappeared on TLC. The reaction mixture was poured into water and extracted with 
Table 1. Yields of Hex-5-enopyranosides and By-products under Conditions (A and B)

\begin{tabular}{|c|c|c|c|c|c|c|c|c|c|c|}
\hline \multirow{2}{*}{ Substrates } & \multicolumn{5}{|c|}{ Conditions (A) } & \multicolumn{5}{|c|}{ Conditions (B) } \\
\hline & \multicolumn{2}{|c|}{ 5-Enopyranosides } & \multicolumn{3}{|c|}{ Others } & \multicolumn{2}{|c|}{ 5-Enopyranosides } & \multicolumn{3}{|c|}{ Others } \\
\hline 1 & 2 & $32 \%$ & 3 & $28 \%, \quad 4$ & $9 \%$ & 2 & $85 \%$ & & & \\
\hline 5 & 6 & $28 \%$ & 7 & $38 \%$ & & 6 & $88 \%$ & & & \\
\hline 8 & 9 & $10 \%$ & 10 & $22 \%, 11$ & $20 \%$ & 9 & $84 \%$ & & & \\
\hline 12 & 13 & $86 \%$ & & & & & & & & \\
\hline 14 & 15 & $78 \%$ & & & & 15 & $95 \%$ & & & \\
\hline 16 & 17 & $80 \%$ & & & & 17 & $84 \%$ & & & \\
\hline 18 & 19 & $82 \%$ & & & & 19 & $84 \%$ & & & \\
\hline 20 & 21 & $92 \%$ & & & & 21 & $94 \%$ & & & \\
\hline 22 & 23 & $54 \%$ & 24 & $18 \%$ & & 23 & $86 \%$ & & & \\
\hline 25 & 26 & $27 \%$ & 27 & $16 \%$ & & 26 & $52 \%$ & 27 & $6 \%$ & \\
\hline 28 & 29 & $13 \%$ & 30 & $18 \%, \mathbf{3 1}$ & $7 \%$ & 29 & $16 \%$ & 30 & $20 \%, 31$ & $11 \%$ \\
\hline
\end{tabular}

Conditions (A): DBU/DMSO, $80-110^{\circ} \mathrm{C}$. Conditions (B): NaI, $n-\mathrm{Bu}_{4} \mathrm{NI}$, MS 4A, $\mathrm{DBU} / \mathrm{DMSO}, 80-110^{\circ} \mathrm{C}$.
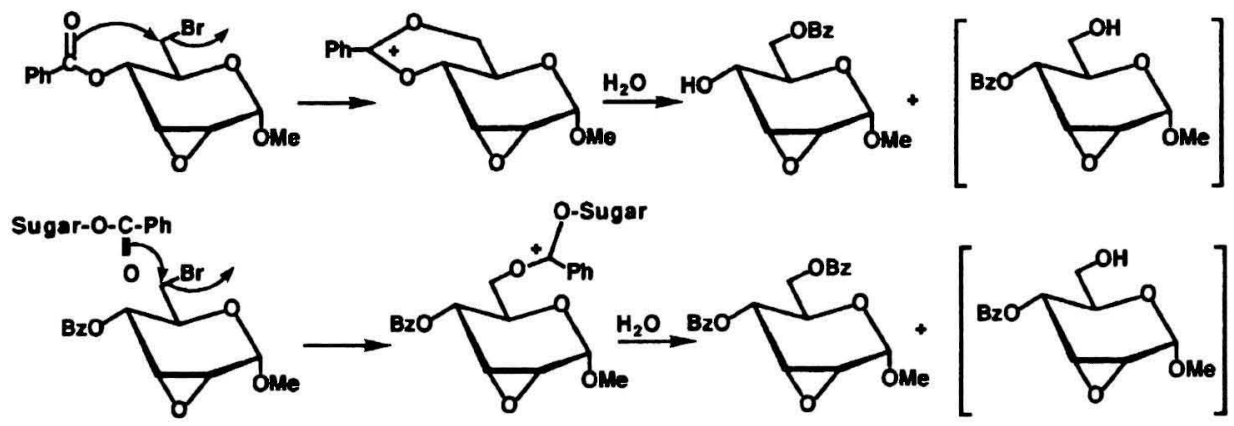

Scheme 2.

Table 2. Yields of Methyl-Branched Hex-5-enopyranosides under Conditions (B)

\begin{tabular}{ccc}
\hline Substrates & \multicolumn{2}{c}{ 5-Enopyranosides } \\
\hline $\mathbf{3 2}$ & $\mathbf{3 3}$ & $74 \%$ \\
$\mathbf{3 4}$ & $\mathbf{3 5}$ & $78 \%$ \\
$\mathbf{3 6}$ & $\mathbf{3 7}$ & $86 \%$ \\
$\mathbf{3 8}$ & $\mathbf{3 9}$ & $75 \%$ \\
$\mathbf{4 0}$ & $\mathbf{4 1}$ & $81 \%$ \\
$\mathbf{4 2}$ & $\mathbf{4 3}$ & $80 \%$ \\
$\mathbf{4 4}$ & $\mathbf{4 5}$ & $91 \%$ \\
\hline
\end{tabular}

ethyl acetate several times. The combined organic layer was washed with a small amount of water, dried, and evaporated to give products.

Conditions (B): A stirring mixture of the substrate (0.5 mmol), sodium iodide (NaI, $2.5 \mathrm{mmol})$, tetrabutylammonium iodide $\left(n-\mathrm{Bu}_{4} \mathrm{NI}, 0.25 \mathrm{mmol}\right)$, and molecular sieves $4 \mathrm{~A}$ (10 pieces) in DMSO $\left(4.0 \mathrm{~cm}^{3}\right)$ was heated under argon at $80-110^{\circ} \mathrm{C}$ until the starting compound disappeared on TLC. Then, DBU $(0.6 \mathrm{mmol})$ was added into the reaction mixture, which was kept at $80-110^{\circ} \mathrm{C}$ (one-pot reaction) until the 6-iodo derivative disappeared. In a similar work up of the reaction mixture, as mentioned in conditions (A), 6-deoxyhex-5-enopyranoside was obtained.

Elimination Reactions of Gluco Series $(1,5,8$, and 12) under the Conditions ( $A$ and $B$ ). Methyl 4$O$-Benzoyl-6-deoxy-2,3-di- $O$-methyl- $\alpha$-D- $x y l o$-hex-5enopyranoside (2), Methyl 4,6-Di- $O$-benzoyl-2,3-di-
$O$-methyl- $\alpha$-D-glucopyranoside (3), and Methyl 6$O$-Benzoyl-2,3-di- $O$-methyl- $\alpha$-D-glucopyranoside (4). Conditions (A): A mixture of methyl 4-O-benzoyl-6-bromo-6-deoxy-2,3-di- $O$-methyl- $\alpha$-D-glucopyranoside 1 (200 mg, $0.51 \mathrm{mmol}$ ) and 1,8-diazabicyclo[5.4.0]undec-7-ene (DBU, 94 $\mathrm{mg}, 0.62 \mathrm{mmol}$ ) in dry dimethyl sulfoxide (DMSO, $6.0 \mathrm{~cm}^{3}$ ) was heated at $110^{\circ} \mathrm{C}$ for $3.5 \mathrm{~h}$. The reaction mixture was poured into water and extracted with ethyl acetate several times. The combined organic layer was washed with a small amount of water, dried and evaporated to give a mixture of products. The mixture was purified on preparative TLC (Kieselgel 60, ether-ethyl acetate-hexane $=1: 1: 2$ ) to give the desired 6-deoxyhex-5-enopyranoside 2 , and by-products 4,6-di- $O$-benzoyl derivative 3 and $6-O$-benzoyl derivative 4 in 32,28 , and $9 \%$ yields, respectively.

2: $\quad$ Mp 109- $110^{\circ} \mathrm{C}$ (ethanol); $[\alpha]_{\mathrm{D}}^{25}+122^{\circ}$ (c 0.3 ); IR $1728(\mathrm{C}=\mathrm{O}), 1668(\mathrm{C}=\mathrm{C}) ;{ }^{1} \mathrm{H}$ NMR $\delta=8.18-8.06$ and 7.65 $7.44(5 \mathrm{H}, \mathrm{m}, \mathrm{Ph}), 5.58\left(1 \mathrm{H}, \mathrm{ddd}, J_{4,6}=2.0 \mathrm{~Hz}, J_{4,6^{\prime}}=2.0 \mathrm{~Hz}\right.$, $\left.J_{4,3}=9.3 \mathrm{~Hz}, \mathrm{H}-4\right), 4.96\left(1 \mathrm{H}, \mathrm{d}, J_{1,2}=3.4 \mathrm{~Hz}, \mathrm{H}-1\right), 4.72(1 \mathrm{H}$, dd, $\left.J_{6,6^{\prime}}=1.8 \mathrm{~Hz}, \mathrm{H}-6\right), 4.56\left(1 \mathrm{H}, \mathrm{dd}, \mathrm{H}-6^{\prime}\right), 3.79(1 \mathrm{H}, \mathrm{dd}, \mathrm{H}-$ $3), 3.59,3.53$, and $3.52(3 \mathrm{H} \times 3$, each $\mathrm{s}, \mathrm{OMe} \times 3), 3.49(1 \mathrm{H}$, $\left.\mathrm{dd}, J_{2,3}=9.3 \mathrm{~Hz}, \mathrm{H}-2\right)$. Found: $\mathrm{C}, 62.08 ; \mathrm{H}, 6.63 \%$. Calcd for $\mathrm{C}_{16} \mathrm{H}_{20} \mathrm{O}_{6}$ : $\mathrm{C}, 62.32 ; \mathrm{H}, 6.54 \%$.

3: $\quad$ Mp $121-122^{\circ} \mathrm{C}$ (ethanol); $[\alpha]_{\mathrm{D}}^{25}+132^{\circ}($ c 0.7$)$; IR $1725(\mathrm{C}=\mathrm{O}) ;{ }^{1} \mathrm{H}$ NMR $\delta=8.10-8.00$ and $7.62-7.35(5 \mathrm{H} \times 2$, $\mathrm{m}, \mathrm{Ph} \times 2), 5.32\left(1 \mathrm{H}, \mathrm{dd}, J_{4,5}=10.0 \mathrm{~Hz}, \mathrm{H}-4\right), 4.92(1 \mathrm{H}, \mathrm{d}$, $\left.J_{1,2}=3.4 \mathrm{~Hz}, \mathrm{H}-1\right), 4.54\left(1 \mathrm{H}, \mathrm{dd}, J_{5,6}=2.9 \mathrm{~Hz}, J_{6,6^{\prime}}=12.0\right.$ $\mathrm{Hz}, \mathrm{H}-6), 4.35\left(1 \mathrm{H}, \mathrm{dd}, J_{5,6^{\prime}}=5.4 \mathrm{~Hz}, \mathrm{H}-6^{\prime}\right), 4.16(1 \mathrm{H}$, ddd, $\mathrm{H}-5), 3.79\left(1 \mathrm{H}, \mathrm{dd}, J_{3,2}=9.6 \mathrm{~Hz}, J_{3,4}=9.4 \mathrm{~Hz}, \mathrm{H}-3\right), 3.57$, 
3.51, and $3.49(3 \mathrm{H} \times 3$, each $\mathrm{s}, \mathrm{OMe} \times 3), 3.41(1 \mathrm{H}, \mathrm{dd}, \mathrm{H}-2)$. Found: $\mathrm{C}, 64.44 ; \mathrm{H}, 6.31 \%$. Calcd for $\mathrm{C}_{23} \mathrm{H}_{26} \mathrm{O}_{8}$ : C, 64.17; $\mathrm{H}, 6.09 \%$.

4: $\mathrm{Mp} 68-71^{\circ} \mathrm{C}$ (ethanol-hexane); $[\alpha]_{D}^{25}+94^{\circ}(c 0.5)$; IR $3475(\mathrm{OH}), 1722(\mathrm{C}=\mathrm{O}) ;{ }^{1} \mathrm{H}$ NMR $\delta=8.08-8.03$ and $7.62-$ $7.40(5 \mathrm{H}, \mathrm{m}, \mathrm{Ph}), 4.87\left(1 \mathrm{H}, \mathrm{d}, J_{1,2}=3.4 \mathrm{~Hz}, \mathrm{H}-1\right), 4.68(1 \mathrm{H}$, $\left.\mathrm{dd}, J_{5,6}=4.8 \mathrm{~Hz}, J_{6,6^{\prime}}=12.2 \mathrm{~Hz}, \mathrm{H}-6\right), 4.54\left(1 \mathrm{H}, \mathrm{dd}, J_{5,6^{\prime}}=2.2\right.$ $\left.\mathrm{Hz}, \mathrm{H}-6^{\prime}\right), 3.89\left(1 \mathrm{H}\right.$, ddd, $\left.J_{5,4}=9.8 \mathrm{~Hz}, \mathrm{H}-5\right), 3.66,3.51$, and $3.46(3 \mathrm{H} \times 3$, each $\mathrm{s}, \mathrm{OMe} \times 3), 3.51(2 \mathrm{H}, \mathrm{m}, \mathrm{H}-3$ and $\mathrm{H}-4)$, $3.25\left(1 \mathrm{H}, \mathrm{dd}, J_{2,3}=9.5 \mathrm{~Hz}, \mathrm{H}-2\right), 2.91(1 \mathrm{H}, \mathrm{s}, \mathrm{OH})$. Found: C, $58.79 ; \mathrm{H}, 6.59 \%$. Calcd for $\mathrm{C}_{16} \mathrm{H}_{22} \mathrm{O}_{7}$ : C, $58.88 ; \mathrm{H}, 6.80 \%$.

Conditions (B): A mixture of compound $1(200 \mathrm{mg}$, $0.51 \mathrm{mmol}$ ), sodium iodide ( $\mathrm{NaI}, 385 \mathrm{mg}, 2.57 \mathrm{mmol}$ ), tetrabutylammonium iodide $\left(\mathrm{Bu}_{4} \mathrm{NI}, 94 \mathrm{mg}, 0.25 \mathrm{mmol}\right)$, and molecular sieves $4 \mathrm{~A}$ (10 pieces) in DMSO $\left(4.0 \mathrm{~cm}^{3}\right)$ was heated at $80^{\circ} \mathrm{C}$ for $5 \mathrm{~h}$ until the starting compound 1 disappeared on TLC (benzene-acetone $=8: 1)$. Then, DBU $(94$ $\mathrm{mg}, 0.62 \mathrm{mmol}$ ) was added to the reaction mixture, which was kept for an additional $6 \mathrm{~h}$ at $80^{\circ} \mathrm{C}$ (one-pot reaction). In a similar work up of the reaction mixture under conditions (A), 6-deoxyhex-5-enopyranoside 2 was obtained in $85 \%$ yield.

Methyl 4-O-Benzyl-6-deoxy-2,3-di- $O$-methyl- $\alpha$-Dxylo-hex-5-enopyranoside (6) and Methyl 4-O-Benzyl-2,3-di- $O$-methyl- $\alpha$-D-glucopyranoside (7). Conditions (A): A mixture of methyl 4- $O$-benzyl-2,3-di- $O$ methyl-6- $O$ - $p$-tolylsulfonyl- $\alpha$-D-glucopyranoside $5(218 \mathrm{mg}$, $0.47 \mathrm{mmol}$ ) and DBU (86 $\mathrm{mg}, 0.57 \mathrm{mmol})$ in dry DMSO $\left(4.0 \mathrm{~cm}^{3}\right)$ was heated at $100^{\circ} \mathrm{C}$ for $7 \mathrm{~h}$. The reaction mixture was worked up in a similar manner as for the reaction of compound 1 ; the products were purified on preparative TLC (ethyl acetate-hexane $=1: 2$ ) to give the desired 6-deoxyhex-5-enopyranoside 6 and 6 -hydroxy by-product $7^{8)}$ in 28 and $38 \%$ yields, respectively.

6: Syrup; $[\alpha]_{\mathrm{D}}^{25}+62.0^{\circ}\left(\right.$ c 1.2); IR $1665(\mathrm{C}=\mathrm{C}) ;{ }^{1} \mathrm{H}$ NMR $\delta=7.42-7.29(5 \mathrm{H}, \mathrm{m}, \mathrm{Ph}), 4.88\left(1 \mathrm{H}, \mathrm{d}, J_{4,6}=2.0 \mathrm{~Hz}, J_{6,6^{\prime}}=0\right.$ $\mathrm{Hz}, \mathrm{H}-6), 4.87\left(1 \mathrm{H}, \mathrm{d}, J_{1,2}=3.4 \mathrm{~Hz}, \mathrm{H}-1\right), 4.78(2 \mathrm{H}, \mathrm{s}$, $\left.-\mathrm{CH}_{2}-\right), 4.72\left(1 \mathrm{H}, \mathrm{d}, J_{4,6^{\prime}}=2.0 \mathrm{~Hz}, \mathrm{H}-6^{\prime}\right), 3.83(1 \mathrm{H}$, ddd, $\left.J_{4,3}=8.8 \mathrm{~Hz}, \mathrm{H}-4\right), 3.64,3.55$, and $3.45(3 \mathrm{H} \times 3$, each $\mathrm{s}$, OMe $\times 3), 3.60\left(1 \mathrm{H}, \mathrm{dd}, J_{3,2}=9.3 \mathrm{~Hz}, \mathrm{H}-3\right), 3.32(1 \mathrm{H}$, dd, $\mathrm{H}-2$ ). Found: $\mathrm{C}, 64.63 ; \mathrm{H}, 7.64 \%$. Calcd for $\mathrm{C}_{16} \mathrm{H}_{22} \mathrm{O}_{5}$ : C, $65.29 ; \mathrm{H}, 7.53 \%$.

7: $\quad \mathrm{Mp} 95-96^{\circ} \mathrm{C}$ (hexane); $[\alpha]_{\mathrm{D}}^{24}+162^{\circ}(c$ 0.8)

Conditions (B): After a mixture of $6-O$ - $p$-tolylsulfonyl derivative 5 (218 $\mathrm{mg}, 0.47 \mathrm{mmol})$, NaI (351 mg, 2.34 $\mathrm{mmol}$ ), Bu $4 \mathrm{NI}$ ( $86 \mathrm{mg}, 0.23 \mathrm{mmol}$ ), and molecular sieves $4 \mathrm{~A}$ in DMSO $\left(4.0 \mathrm{~cm}^{3}\right)$ was stirred under argon at $80^{\circ} \mathrm{C}$ for $3 \mathrm{~h}, \mathrm{DBU}(86 \mathrm{mg}, 0.57 \mathrm{mmol}$ ) was added and kept for an additional $3 \mathrm{~h}$ at $80^{\circ} \mathrm{C}$. A similar work up of the reaction mixture as mentioned above gave 6 in $88 \%$ yield.

Methyl 4- $O$-Acetyl-2,3-di- $O$-benzoyl-6-deoxy- $\alpha$-Dxylo-hex-5-enopyranoside (9), Methyl 4-O-Acetyl2,3,6-tri- $O$-benzoyl- $\alpha$-D-glucopyranoside (10), and Methyl 4,6-Di- $O$-acetyl-2,3-di- $O$-benzoyl- $\alpha$-D-glucopyranoside (11). Conditions (A): A mixture of methyl 4- $O$-acetyl-2,3-di- $O$-benzoyl-6- $O$ - $p$-tolylsulfonyl- $\alpha$-Dglucopyranoside $8(218 \mathrm{mg}, 0.37 \mathrm{mmol})$ and DBU $(67 \mathrm{mg}$, $0.44 \mathrm{mmol}$ ) in DMSO $\left(4.0 \mathrm{~cm}^{3}\right)$ was stirred at $100^{\circ} \mathrm{C}$ for 5 $\mathrm{h}$ under argon. The reaction mixture was worked up in a similar manner as mentioned above and the products were purified on preparative TLC (ether-ethyl acetate-hexane $=1: 1: 2)$ to give the desired product 9 as well as by-products
10 and 11 in 10,22 , and $20 \%$ yields, respectively.

9: $\quad \mathrm{Mp} 111-112^{\circ} \mathrm{C}$ (ethanol); $[\alpha]_{\mathrm{D}}^{24}+140.5^{\circ}$ (c 0.4); IR $1731(\mathrm{C}=\mathrm{O})$ and $1671(\mathrm{C}=\mathrm{C})$; ${ }^{1} \mathrm{H}$ NMR $\delta=7.99-7.94$ and 7.55-7.33 $(5 \mathrm{H} \times 2, \mathrm{~m}, \mathrm{Ph} \times 2), 5.96\left(1 \mathrm{H}, \mathrm{dd}, J_{3,4}=9.8 \mathrm{~Hz}\right.$, $\mathrm{H}-3), 5.75\left(1 \mathrm{H}\right.$, ddd, $\left.J_{4,6}=J_{4,6^{\prime}}=2.0 \mathrm{~Hz}, \mathrm{H}-4\right), 5.32(1 \mathrm{H}$, dd, $\left.J_{2,3}=9.9 \mathrm{~Hz}, \mathrm{H}-2\right), 5.23\left(1 \mathrm{H}, \mathrm{d}, J_{1,2}=3.4 \mathrm{~Hz}, \mathrm{H}-1\right), 4.87$ $\left(1 \mathrm{H}, \mathrm{dd}, J_{6,6^{\prime}}=2.0 \mathrm{~Hz}, \mathrm{H}-6\right), 4.68\left(1 \mathrm{H}, \mathrm{dd}, \mathrm{H}-6^{\prime}\right), 3.48(3 \mathrm{H}$, $\mathrm{s}, \mathrm{OMe}), 2.06(3 \mathrm{H}, \mathrm{s}, \mathrm{OAc})$. Found: $\mathrm{C}, 64.25 ; \mathrm{H}, 4.98 \%$. Calcd for $\mathrm{C}_{23} \mathrm{H}_{22} \mathrm{O}_{8}$ : C, $64.78 ; \mathrm{H}, 5.20 \%$.

10: Amorphous: $[\alpha]_{D}^{25}+149^{\circ}(c 2.8)$; IR $1722(\mathrm{C}=\mathrm{O})$; ${ }^{1} \mathrm{H}$ NMR $\delta=8.12-7.93$ and $7.64-7.33(5 \mathrm{H} \times 3, \mathrm{~m}, \mathrm{Ph} \times 3)$, $6.00\left(1 \mathrm{H}, \mathrm{dd}, J_{3,2}=9.8 \mathrm{~Hz}, J_{3,4}=9.7 \mathrm{~Hz}, \mathrm{H}-3\right), 5.44(1 \mathrm{H}, \mathrm{dd}$, $\left.J_{4,5}=9.9 \mathrm{~Hz}, \mathrm{H}-4\right), 5.23\left(1 \mathrm{H}, \mathrm{dd}, J_{2,1}=3.4 \mathrm{~Hz}, \mathrm{H}-2\right), 5.19$ $(1 \mathrm{H}, \mathrm{d}, \mathrm{H}-1), 4.57\left(1 \mathrm{H}, \mathrm{dd}, J_{6,5}=2.7 \mathrm{~Hz}, J_{6,6^{\prime}}=12.2 \mathrm{~Hz}, \mathrm{H}-\right.$ 6), $4.46\left(1 \mathrm{H}, \mathrm{dd}, J_{6^{\prime}, 5}=4.9 \mathrm{~Hz}, \mathrm{H}-6^{\prime}\right), 4.34(1 \mathrm{H}, \mathrm{ddd}, \mathrm{H}-5)$, $3.46(3 \mathrm{H}, \mathrm{s}, \mathrm{OMe}), 1.96(3 \mathrm{H}, \mathrm{s}, \mathrm{OAc})$. Found: $\mathrm{C}, 65.17 ; \mathrm{H}$, $5.10 \%$. Calcd for $\mathrm{C}_{30} \mathrm{H}_{28} \mathrm{O}_{10}$ : C, $65.69 ; \mathrm{H}, 5.15 \%$.

11: Syrup: $[\alpha]_{\mathrm{D}}^{24}+141^{\circ}(c 1.6)$; IR $1734(\mathrm{C}=\mathrm{O}) ;{ }^{1} \mathrm{H}$ NMR $\delta=7.99-7.92$ and $7.56-7.33(5 \mathrm{H} \times 2, \mathrm{~m}, \mathrm{Ph} \times 2), 5.96(1 \mathrm{H}$, dd, $\left.J_{3,4}=9.8 \mathrm{~Hz}, J_{3,2}=8.1 \mathrm{~Hz}, \mathrm{H}-3\right), 5.35\left(1 \mathrm{H}, \mathrm{dd}, J_{4,5}=9.9\right.$ $\mathrm{Hz}, \mathrm{H}-4), 5.21\left(1 \mathrm{H}, \mathrm{dd}, J_{2,1}=3.4 \mathrm{~Hz}, J_{2,3}=8.1 \mathrm{~Hz}, \mathrm{H}-2\right), 5.19$ $(1 \mathrm{H}, \mathrm{d}, \mathrm{H}-1), 4.35\left(1 \mathrm{H}, \mathrm{dd}, J_{6,5}=4.6 \mathrm{~Hz}, J_{6,6^{\prime}}=12.3 \mathrm{~Hz}, \mathrm{H}-\right.$ $6), 4.18\left(1 \mathrm{H}, \mathrm{dd}, J_{6^{\prime}, 5}=2.2 \mathrm{~Hz}, \mathrm{H}-6^{\prime}\right), 4.14(1 \mathrm{H}$, ddd, H-5), $3.45(3 \mathrm{H}, \mathrm{s}, \mathrm{OMe}), 2.15$ and $1.96(3 \mathrm{H} \times 2$, each $\mathrm{s}, \mathrm{OAc} \times 2)$. Found: $\mathrm{C}, 62.21 ; \mathrm{H}, 5.50 \%$. Calcd for $\mathrm{C}_{25} \mathrm{H}_{26} \mathrm{O}_{10}$ : C, 61.72; $\mathrm{H}, 5.35 \%$.

Conditions (B): After a mixture of compound 8 (218 $\mathrm{mg}, 0.37 \mathrm{mmol}), \mathrm{NaI}(273 \mathrm{mg}, 1.82 \mathrm{mmol}), \mathrm{Bu}_{4} \mathrm{NI}(68 \mathrm{mg}$, $0.18 \mathrm{mmol}$ ), and molecular sieves $4 \mathrm{~A}$ (10 pieces) in DMSO $\left(4.0 \mathrm{~cm}^{3}\right)$ was stirred for $6 \mathrm{~h}$ at $80^{\circ} \mathrm{C}$ under argon, DBU ( $67 \mathrm{mg}, 0.44 \mathrm{mmol}$ ) was added and kept for an additional $3 \mathrm{~h}$ at $80^{\circ} \mathrm{C}$. A similar work up of the reaction mixture as mentioned above gave $\mathbf{9}$ in $84 \%$ yield.

Methyl 3,6-Anhydro-2,4-di- $O$-benzoyl- $\alpha$-D-glucopyranoside (13). Conditions (A): A mixture of methyl 2,3-di- $O$-benzoyl-6- $O$ - $p$-tolylsulfonyl- $\alpha$-D-glucopyranoside $12(200 \mathrm{mg}, 0.36 \mathrm{mmol})$ and DBU $(65 \mathrm{mg}, 0.43 \mathrm{mmol})$ in DMSO $\left(6.0 \mathrm{~cm}^{3}\right)$ was heated at $80^{\circ} \mathrm{C}$ for $3 \mathrm{~h}$; the usual work up of the reaction mixture and purification gave the 3 , 6 -anhydro derivative 13 in $86 \%$ yield.

13: Syrup; $[\alpha]_{D}^{25}+19.3^{\circ}(c 0.7)$; IR $1725(\mathrm{C}=\mathrm{O}) ;{ }^{1} \mathrm{H}$ NMR $\delta=8.06-7.79$ and $7.58-7.01(5 \mathrm{H} \times 2, \mathrm{~m}, \mathrm{Ph} \times 2), 5.37(1 \mathrm{H}$, dd, $\left.J_{2,1}=3.4 \mathrm{~Hz}, J_{2,3}=4.6 \mathrm{~Hz}, \mathrm{H}-2\right), 5.18(1 \mathrm{H}, \mathrm{d}, \mathrm{H}-1), 5.03$ $\left(1 \mathrm{H}, \mathrm{dd}, J_{4,3}=5.2 \mathrm{~Hz}, J_{4,5}=2.6 \mathrm{~Hz}, \mathrm{H}-4\right), 4.87(1 \mathrm{H}, \mathrm{dd}, \mathrm{H}-$ 3), $4.75\left(1 \mathrm{H}, \mathrm{dd}, J_{5,6}=0 \mathrm{~Hz}, J_{5,6^{\prime}}=2.9 \mathrm{~Hz}, \mathrm{H}-5\right), 4.33(1 \mathrm{H}, \mathrm{d}$, $\left.J_{6,6^{\prime}}=10.7 \mathrm{~Hz}, \mathrm{H}-6\right), 4.12\left(1 \mathrm{H}, \mathrm{dd}, \mathrm{H}-6^{\prime}\right)$. Found: C, 66.01; $\mathrm{H}, 5.59 \%$. Calcd for $\mathrm{C}_{21} \mathrm{H}_{20} \mathrm{O}_{7} ; \mathrm{C}, 65.61 ; \mathrm{H}, 5.24 \%$.

Elimination Reactions of Altro Series (14, 16, and 18) under Conditions ( $A$ and $B$ ). Methyl 3- $O$-Acetyl-2,4-di- $O$-benzoyl-6-deoxy- $\alpha$-D-arabino-hex-5-enopyranoside (15). Conditions (A): A mixture of methyl 3- $O$-acetyl-2,4-di- $O$-benzoyl-6-bromo-6-deoxy- $\alpha$-Daltropyranoside $14(203 \mathrm{mg}, 0.40 \mathrm{mmol})$ and DBU $(74 \mathrm{mg}$, $0.49 \mathrm{mmol})$ in DMSO $\left(4.0 \mathrm{~cm}^{3}\right)$ was heated at $80^{\circ} \mathrm{C}$ for 2 $\mathrm{h}$ under argon. The reaction mixture was worked up in a similar manner to that mentioned above. The product was purified on preparative TLC (ether-ethyl acetate-hexane $=1: 1: 2$ ) to give the corresponding 6-deoxyhex-5-enopyranoside derivative $\mathbf{1 5}$ in $78 \%$ yield.

15: Syrup; $[\alpha]_{\mathrm{D}}^{25}-38^{\circ}$ (c 1.0); IR $1731(\mathrm{C}=\mathrm{O}), 1668$ $(\mathrm{C}=\mathrm{C}) ;{ }^{1} \mathrm{H}$ NMR $\delta=8.13-8.03$ and $7.64-7.43(5 \mathrm{H} \times 2, \mathrm{~m}$, $\mathrm{Ph} \times 2), 6.03\left(1 \mathrm{H}, \mathrm{d}, J_{4,3}=3.7 \mathrm{~Hz}, \mathrm{H}-4\right), 5.67\left(1 \mathrm{H}, \mathrm{dd}, J_{2,1}=\right.$ 
$\left.5.4 \mathrm{~Hz}, J_{2,3}=8.8 \mathrm{~Hz}, \mathrm{H}-2\right), 5.42(1 \mathrm{H}, \mathrm{dd}, \mathrm{H}-3), 4.97(1 \mathrm{H}, \mathrm{d}$, $\left.J_{6,6^{\prime}}=1.2 \mathrm{~Hz}, \mathrm{H}-6\right), 4.88\left(1 \mathrm{H}, \mathrm{d}, \mathrm{H}-6^{\prime}\right), 4.80(1 \mathrm{H}, \mathrm{d}, \mathrm{H}-1)$, $3.58(3 \mathrm{H}, \mathrm{s}, \mathrm{OMe}), 1.96(3 \mathrm{H}, \mathrm{s}, \mathrm{OAc})$. Found: $\mathrm{C}, 65.02 ; \mathrm{H}$, $5.23 \%$. Calcd for $\mathrm{C}_{23} \mathrm{H}_{22} \mathrm{O}_{8}$ : C, $64.78 ; \mathrm{H}, 5.20 \%$.

Conditions (B): After a mixture of compound 14 (203 $\mathrm{mg}, 0.40 \mathrm{mmol}$ ), NaI (304 mg, $2.03 \mathrm{mmol}), \mathrm{Bu}_{4} \mathrm{NI}(75 \mathrm{mg}$, $0.20 \mathrm{mmol})$, and molecular sieves $4 \mathrm{~A}$ (10 pieces) in DMSO $\left(4.0 \mathrm{~cm}^{3}\right)$ was treated at $80^{\circ} \mathrm{C}$ for $3 \mathrm{~h}$ under argon, DBU $(74$ $\mathrm{mg}, 0.49 \mathrm{mmol}$ ) was added and kept for $1.5 \mathrm{~h}$ at $80^{\circ} \mathrm{C}$. A similar work up of the reaction mixture as mentioned above gave $\mathbf{1 5}$ in $95 \%$ yield.

Methyl 3-Acetamido- 2- $O$ - acetyl-4- $O$-benzoyl-3, 6-dideoxy- $\alpha$-D-arabino- hex-5-enopyranoside (17). Conditions (A): A mixture of methyl 3-acetamido-2$O$-acetyl-4- $O$-benzoyl-6-bromo-3,6-dideoxy- $\alpha$-D-altropyranoside $16(201 \mathrm{mg}, 0.45 \mathrm{mmol})$ and DBU $(82 \mathrm{mg}, 0.54 \mathrm{mmol})$ in DMSO $\left(5.0 \mathrm{~cm}^{3}\right)$ was stirred at $80^{\circ} \mathrm{C}$ for $2 \mathrm{~h}$ under argon; usual work up of the reaction mixture and purification on preparative TLC gave $\mathbf{1 7}$ in $80 \%$ yield.

17: Syrup; $[\alpha]_{\mathrm{D}}^{24}-14.4^{\circ}(c$ 0.6); IR $3430(\mathrm{~N}-\mathrm{H}), 1728$ $(\mathrm{C}=\mathrm{O}), 1668(\mathrm{HN}-\mathrm{C}=\mathrm{O}, \mathrm{C}=\mathrm{C}) ;{ }^{1} \mathrm{H}$ NMR $\delta=8.05-8.00$ and $7.62-7.40(5 \mathrm{H}, \mathrm{m}, \mathrm{Ph}), 6.35\left(1 \mathrm{H}, \mathrm{d}, J_{\mathrm{NH}, 3}=9.8 \mathrm{~Hz}, \mathrm{NH}\right)$, $5.84\left(1 \mathrm{H}, \mathrm{d}, J_{4,3}=4.4 \mathrm{~Hz}, \mathrm{H}-4\right), 5.02\left(1 \mathrm{H}, \mathrm{dd}, J_{2,1}=2.9 \mathrm{~Hz}\right.$, $\left.J_{2,3}=5.4 \mathrm{~Hz}, \mathrm{H}-2\right), 4.91(1 \mathrm{H}, \mathrm{s}, \mathrm{H}-6), 4.81\left(1 \mathrm{H}, \mathrm{s}, \mathrm{H}-6^{\prime}\right)$, $4.77(1 \mathrm{H}, \mathrm{d}, \mathrm{H}-1), 4.76$ (1H, ddd, H-3), $3.55(3 \mathrm{H}, \mathrm{s}, \mathrm{OMe})$, $2.15(3 \mathrm{H}, \mathrm{s}, \mathrm{OAc}), 1.95$ (3H, s, NAc). Found: C, 59.63; H, $5.57 ; \mathrm{N}, 3.61 \%$. Calcd for $\mathrm{C}_{18} \mathrm{H}_{21} \mathrm{NO}_{7}: \mathrm{C}, 59.49 ; \mathrm{H}, 5.83 ; \mathrm{N}$, $3.86 \%$.

Conditions (B): After a mixture of the compound 16 (201 mg, $0.45 \mathrm{mmol}), \mathrm{NaI}(340 \mathrm{mg}, 2.27 \mathrm{mmol}), \mathrm{Bu}_{4} \mathrm{NI}$ ( $84 \mathrm{mg}, 0.23 \mathrm{mmol})$, and molecular sieves $4 \mathrm{~A}$ (10 pieces) in DMSO $\left(4.0 \mathrm{~cm}^{3}\right)$ was stirred for $4 \mathrm{~h}$ at $80^{\circ} \mathrm{C}$ under argon, DBU ( $83 \mathrm{mg}, 0.55 \mathrm{mmol}$ ) was added and kept for an additional $1.5 \mathrm{~h}$ at $80^{\circ} \mathrm{C}$. A similar work up of the reaction mixture and purification gave 17 in $84 \%$ yield.

Methyl 3- $O$-Acetyl-2-azido-4- $O$-benzoyl-2,6-dideoxy- $\alpha$-D-arabino-hex-5-enopyranoside (19). Conditions (A): A mixture of methyl 3- $O$-acetyl-2-azido-4$O$-benzoyl-6-bromo-2,6-dideoxy- $\alpha$-D-altropyranoside 18 (102 $\mathrm{mg}, 0.24 \mathrm{mmol}$ ) and DBU ( $45 \mathrm{mg}, 0.30 \mathrm{mmol})$ in DMSO (1.5 $\mathrm{cm}^{3}$ ) was stirred for $2 \mathrm{~h}$ at $80^{\circ} \mathrm{C}$ under argon. The reaction mixture was worked up in the usual manner to give syrupy 19, which was purified on a column of silica gel (hexaneethyl acetate $=2: 1)$ in $82 \%$ yield.

19: Syrup: $[\alpha]_{D}^{25}+18.1^{\circ}(c 0.5)$; IR $2116\left(\mathrm{~N}_{3}\right), 1758$ and $1728(\mathrm{C}=\mathrm{O}), 1668(\mathrm{C}=\mathrm{C}) ;{ }^{1} \mathrm{H}$ NMR $\delta=8.09-7.43(5 \mathrm{H}$, $\mathrm{m}, \mathrm{Ph}), 5.88\left(1 \mathrm{H}, \mathrm{d}, J_{4,3}=3.4, \mathrm{H}-4\right), 4.95\left(1 \mathrm{H}, \mathrm{d}, J_{6,6^{\prime}}=1.5\right.$, $\mathrm{H}-6), 4.94(1 \mathrm{H}, \mathrm{dd}, \mathrm{H}-3), 4.87\left(1 \mathrm{H}, \mathrm{d}, \mathrm{H}-6^{\prime}\right), 4.42(1 \mathrm{H}, \mathrm{d}$, $\left.J_{1,2}=7.6 \mathrm{~Hz}, \mathrm{H}-1\right), 3.98\left(1 \mathrm{H}, \mathrm{dd}, J_{2,3}=10.8 \mathrm{~Hz}, \mathrm{H}-2\right), 3.68$ (3H, s, OMe), 2.05 (3H, s, OAc). Found: C, 55.12; H, 4.78; $\mathrm{N}, 11.70 \%$. Calcd for $\mathrm{C}_{16} \mathrm{H}_{17} \mathrm{~N}_{3} \mathrm{O}_{6}: \mathrm{C}, 55.33 ; \mathrm{H}, 4.93 ; \mathrm{N}$, $12.10 \%$.

Conditions (B): After a mixture of the compound $\mathbf{1 8}$ (216 mg, $0.50 \mathrm{mmol}), \mathrm{NaI}(378 \mathrm{mg}, 2.52 \mathrm{mmol})$, and $\mathrm{Bu}_{4} \mathrm{NI}$ $(93 \mathrm{mg}, 0.25 \mathrm{mmol})$ in DMSO $\left(5.0 \mathrm{~cm}^{3}\right)$ was stirred for $3 \mathrm{~h}$ at $80^{\circ} \mathrm{C}$ under argon, DBU (93 $\mathrm{mg}, 0.61 \mathrm{mmol}$ ) and molecular sieves $4 \mathrm{~A}$ (10 pieces) were added and kept for an additional $1.5 \mathrm{~h}$ at $80^{\circ} \mathrm{C}$. A similar work up of the reaction mixture as mentioned above gave 19 in $84 \%$ yield.

Elimination Reactions of 2-Deoxyribo Series (20 and 22) under Conditions (A and B). Methyl 3, 4-Di- $O$-Benzoyl-2,6-dideoxy- $\alpha$-D-erythro-hex-5-eno- pyranoside (21). Conditions (A): A mixture of methyl 3,4-di- $O$-benzoyl-6-bromo-2,6-dideoxy- $\alpha$-D-ribo-hexopyranoside $20(266 \mathrm{mg}, 0.59 \mathrm{mmol})$ and DBU (108 $\mathrm{mg}, 0.71$ $\mathrm{mmol})$ in DMSO $\left(4.0 \mathrm{~cm}^{3}\right)$ was stirred for $2 \mathrm{~h}$ at $80^{\circ} \mathrm{C}$ under argon. The reaction mixture was purified on preparative TLC $\left(\mathrm{CCl}_{4}\right.$-ether $\left.=5: 2\right)$ to give the corresponding product 21 in $92 \%$ yield.

21: Syrup; $[\alpha]_{D}^{25}+122^{\circ}$ (c 1.0); IR $1725(\mathrm{C}=0), 1665$ $(\mathrm{C}=\mathrm{C}) ;{ }^{1} \mathrm{H} \mathrm{NMR} \delta=8.06-7.95$ and $7.60-7.34(5 \mathrm{H} \times 2, \mathrm{~m}$, $\mathrm{Ph} \times 2), 5.87\left(1 \mathrm{H}, \mathrm{d}, J_{4,3}=3.2 \mathrm{~Hz}, \mathrm{H}-4\right), 5.48\left(1 \mathrm{H}, \mathrm{ddd}, J_{3,2 \mathrm{a}}=\right.$ $\left.8.1 \mathrm{~Hz}, J_{3,2 \mathrm{e}}=4.8 \mathrm{~Hz}, \mathrm{H}-3\right), 4.90\left(1 \mathrm{H}, \mathrm{d}, J_{6,6^{\prime}}=1.0 \mathrm{~Hz}, \mathrm{H}-6\right)$, $4.83\left(1 \mathrm{H}, \mathrm{dd}, J_{1,2 \mathrm{a}}=5.7 \mathrm{~Hz}, J_{1,2 \mathrm{e}}=3.9 \mathrm{~Hz}, \mathrm{H}-1\right), 4.82(1 \mathrm{H}, \mathrm{d}$, $\left.\mathrm{H}-6^{\prime}\right), 3.58(3 \mathrm{H}, \mathrm{s}, \mathrm{OMe}), 2.43\left(1 \mathrm{H}\right.$, ddd, $J_{2 \mathrm{a}, 2 \mathrm{e}}=13.6 \mathrm{~Hz}, \mathrm{H}-$ 2a), 2.35 (1H, ddd, H-2e). Found: C, $68.21 ; \mathrm{H}, 5.44 \%$. Calcd for $\mathrm{C}_{21} \mathrm{H}_{20} \mathrm{O}_{6} ; \mathrm{C}, 68.47 ; \mathrm{H}, 5.47 \%$. [Ref. $3:[\alpha]_{\mathrm{D}}^{23}+123^{\circ}(c$ 2.9); IR $1730(\mathrm{C}=\mathrm{O}), 1660(\mathrm{C}=\mathrm{C}) ;{ }^{1} \mathrm{H} N \mathrm{NR}$ : in benzene- $d_{6}$ $\delta=8.14-8.00$ and $7.20-6.86(5 \mathrm{H} \times 2, \mathrm{~m}, \mathrm{Ph} \times 2), 5.96(1 \mathrm{H}$, d, $\left.J_{4,3}=3.2 \mathrm{~Hz}, \mathrm{H}-4\right), 5.37\left(1 \mathrm{H}\right.$, ddd, $J_{3,2 \mathrm{a}}=8.9 \mathrm{~Hz}, J_{3,2 \mathrm{e}}=4.2$ $\mathrm{Hz}, \mathrm{H}-3), 4.75\left(1 \mathrm{H}, \mathrm{d}, J_{6,6^{\prime}}=1.0 \mathrm{~Hz}, \mathrm{H}-6\right), 4.65(1 \mathrm{H}, \mathrm{d}, \mathrm{H}-$ $\left.6^{\prime}\right), 4.33\left(1 \mathrm{H}, \mathrm{dd}, J_{1,2 \mathrm{a}}=6.2 \mathrm{~Hz}, J_{1,2 \mathrm{e}}=3.5 \mathrm{~Hz}, \mathrm{H}-1\right), 3.25$ $(3 \mathrm{H}, \mathrm{s}, \mathrm{OMe}), 2.32\left(1 \mathrm{H}, \mathrm{ddd}, J_{2 \mathrm{a}, 2 \mathrm{e}}=13.5 \mathrm{~Hz}, \mathrm{H}-2 \mathrm{a}\right), 1.92$ (1H, ddd, H-2e)].

Conditions (B): After a mixture of the compound 20 (266 mg, $0.59 \mathrm{mmol})$, NaI (534 mg, $3.56 \mathrm{mmol})$, and $\mathrm{Bu}_{4} \mathrm{NI}$ $(109 \mathrm{mg}, 0.30 \mathrm{mmol})$ in DMSO $\left(4.0 \mathrm{~cm}^{3}\right)$ was stirred for 3 $\mathrm{h}$ at $80^{\circ} \mathrm{C}$ under argon until the disappearance of 20 (TLC: $\mathrm{CCl}_{4}$-ether $\left.=5: 2\right)$, DBU $(108 \mathrm{mg}, 0.71 \mathrm{mmol})$ and molecular sieves $4 \mathrm{~A}$ (10 pieces) were added and kept for an additional $1.5 \mathrm{~h}$ at $80^{\circ} \mathrm{C}$. A similar work up of the reaction mixture, the purification of the product on TLC (as mentioned above) gave product $\mathbf{2 1}$ in $94 \%$ yield.

Methyl 3- $O$-Benzoyl-2,6-dideoxy-4- $O$-methyl- $\alpha$-Derythro-hex-5-enopyranoside (23) and Methyl 3,6-di$O$-benzoyl-2-deoxy-4- $O$-methyl- $\alpha$-D-ribo-hexopyranoside (24). Conditions (A): A mixture of methyl 3$O$-benzoyl-6-bromo-2,6-dideoxy-4- $O$-methyl- $\alpha$-D-ribo-hexopyranoside (22) (180 mg, $0.50 \mathrm{mmol}$ ) and DBU (92 $\mathrm{mg}, 0.61$ $\mathrm{mmol})$ in DMSO $\left(5.0 \mathrm{~cm}^{3}\right)$ was stirred at $100^{\circ} \mathrm{C}$ for $3 \mathrm{~h}$. The products were extracted with ethyl acetate and purified on TLC (ether-hexane $=1: 1$ ) to give the desired compound 23 and by-product 24 in 54 and $18 \%$ yields, respectively.

23: Syrup; $[\alpha]_{\mathrm{D}}^{24}+116^{\circ}$ (c 1.3); IR $1728(\mathrm{C}=\mathrm{O}), 1668$ $(\mathrm{C}=\mathrm{C}) ;{ }^{1} \mathrm{H}$ NMR $\delta=8.18-8.05$ and $7.61-7.40(5 \mathrm{H}, \mathrm{m}, \mathrm{Ph})$, $5.26\left(1 \mathrm{H}\right.$, ddd, $J_{3,4}=3.2 \mathrm{~Hz}, J_{3,2 \mathrm{a}}=10.0 \mathrm{~Hz}, J_{3,2 \mathrm{e}}=3.2 \mathrm{~Hz}, \mathrm{H}-$ $3), 4.87(1 \mathrm{H}, \mathrm{s}, \mathrm{H}-6), 4.69\left(1 \mathrm{H}, \mathrm{dd}, J_{1,2 \mathrm{a}}=7.4 \mathrm{~Hz}, J_{1,2 \mathrm{e}}=3.2\right.$ $\mathrm{Hz}, \mathrm{H}-1), 4.66\left(1 \mathrm{H}, \mathrm{s}, \mathrm{H}-6^{\prime}\right), 3.94(1 \mathrm{H}, \mathrm{d}, \mathrm{H}-4), 3.55$ and 3.38 $(3 \mathrm{H} \times 2$, each s, OMe $\times 2), 2.38\left(1 \mathrm{H}\right.$, ddd, $J_{2 \mathrm{a}, 2 \mathrm{e}}=13.1 \mathrm{~Hz}, \mathrm{H}-$ 2a), $2.14(1 \mathrm{H}$, ddd, $\mathrm{H}-2 \mathrm{e})$. Found: C, 64.91; H, 6.61\%. Calcd for $\mathrm{C}_{15} \mathrm{H}_{18} \mathrm{O}_{5}$ : C, $64.73 ; \mathrm{H}, 6.52 \%$.

24: Syrup; $[\alpha]_{\mathrm{D}}^{24}+113^{\circ}(c 0.8)$; IR $1725(\mathrm{C}=\mathrm{O}) ;{ }^{1} \mathrm{H}$ NMR $\delta=8.14-8.07$ and $7.62-7.42(5 \mathrm{H} \times 2, \mathrm{~m}, \mathrm{Ph} \times 2), 5.77(1 \mathrm{H}$, ddd, $\left.J_{3,4}=3.2 \mathrm{~Hz}, J_{3,2 \mathrm{e}}=3.2 \mathrm{~Hz}, J_{3,2 \mathrm{a}}=3.2 \mathrm{~Hz}, \mathrm{H}-3\right), 4.82$ $\left(1 \mathrm{H}, \mathrm{d}, J_{1,2 \mathrm{a}}=4.2 \mathrm{~Hz}, J_{1,2 \mathrm{e}}=0 \mathrm{~Hz}, \mathrm{H}-1\right), 4.67\left(1 \mathrm{H}, \mathrm{dd}, J_{6,5}=\right.$ $\left.2.2 \mathrm{~Hz}, J_{6,6^{\prime}}=11.5 \mathrm{~Hz}, \mathrm{H}-6\right), 4.56\left(1 \mathrm{H}, \mathrm{dd}, J_{6^{\prime}, 5}=5.4 \mathrm{~Hz}\right.$, H-6 $\left.{ }^{\prime}\right), 4.45\left(1 \mathrm{H}, \mathrm{ddd}, J_{5,4}=9.9 \mathrm{~Hz}, \mathrm{H}-5\right), 3.47(1 \mathrm{H}, \mathrm{dd}, \mathrm{H}-$ 4), 3.43 and $3.39(3 \mathrm{H} \times 2$, each $\mathrm{s}, \mathrm{OMe} \times 2), 2.30(1 \mathrm{H}, \mathrm{dd}$, $\left.J_{2 \mathrm{a}, 2 \mathrm{e}}=15.2 \mathrm{~Hz}, \mathrm{H}-2 \mathrm{e}\right), 2.06(1 \mathrm{H}$, ddd, H-2a). Found: C, $65.88 ; \mathrm{H}, 5.93 \%$. Calcd for $\mathrm{C}_{22} \mathrm{H}_{24} \mathrm{O}_{7}$ : C, $65.99 ; \mathrm{H}, 6.04 \%$.

Conditions (B): After a mixture of 6-bromo-derivative 22 (180 mg, $0.50 \mathrm{mmol}), \mathrm{NaI}(451 \mathrm{mg}, 3.01 \mathrm{mmol})$, and $\mathrm{Bu}_{4} \mathrm{NI}(93 \mathrm{mg}, 0.25 \mathrm{mmol})$ in DMSO $\left(5.0 \mathrm{~cm}^{3}\right)$ was stirred at $80^{\circ} \mathrm{C}$ for $4 \mathrm{~h}$ until the disappearance of the starting com- 
pound 22, DBU (92 $\mathrm{mg}, 0.61 \mathrm{mmol}$ ) and molecular sieves $4 \mathrm{~A}$ (10 pieces) were added and kept for an additional $3 \mathrm{~h}$. The reaction mixture was worked up in a similar manner as conditions (A) to give $\mathbf{2 3}$ in $86 \%$ yield.

Elimination Reactions of 2,3-Anhydro Series (25 and 28) under the Conditions ( $A$ and $B$ ). Methyl 2,3-Anhydro-4- $O$-benzoyl- $\alpha$-D-lyxo-hex-5-enopyranoside (26) and Methyl 2,3-Anhydro-4,6-di- $O$-benzoyl- $\alpha$-D-mannopyranoside (27). Conditions (A): A mixture of methyl 2,3-anhydro-4- $O$ - benzoyl-6-bromo6-deoxy- $\alpha$-D-mannopyranoside (25) $(500 \mathrm{mg}, 1.45 \mathrm{mmol}$ ) and DBU (266 mg, $1.75 \mathrm{mmol}$ ) in dry DMSO $\left(11.5 \mathrm{~cm}^{3}\right)$ was stirred at $80^{\circ} \mathrm{C}$ for $20 \mathrm{~h}$. The reaction mixture was poured into brine and extracted with ethyl acetate several times. The usual work up of the products and purification on a column of silica gel (Wakogel C-300, hexane-eth$\mathrm{yl}$ acetate $=6: 1$ ) gave the corresponding hexosene derivative 26 and 4,6-di- $O$-benzoyl derivative $\mathbf{2 7}$ in 27 and $16 \%$ yields, respectively.

26: Syrup; $[\alpha]_{\mathrm{D}}^{25}+16.2^{\circ}(c$ 0.9); IR $1725(\mathrm{C}=\mathrm{O}), 1659$ $(\mathrm{C}=\mathrm{C}) ;{ }^{1} \mathrm{H}$ NMR $\delta=8.13-7.35(5 \mathrm{H}, \mathrm{m}, \mathrm{Ph}), 5.95(1 \mathrm{H}, \mathrm{d}$, $\left.J_{4,3}=1.7 \mathrm{~Hz}, \mathrm{H}-4\right), 5.17\left(1 \mathrm{H}, \mathrm{d}, J_{1,2}=1.4 \mathrm{~Hz}, \mathrm{H}-1\right), 4.72(1 \mathrm{H}$, d, $\left.J_{6,6^{\prime}}=1.4 \mathrm{~Hz}, \mathrm{H}-6\right), 4.58\left(1 \mathrm{H}, \mathrm{d}, \mathrm{H}-6^{\prime}\right), 3.61(3 \mathrm{H}, \mathrm{s}, \mathrm{OMe})$, $3.50\left(1 \mathrm{H}\right.$, dd, $\left.J_{3,2}=3.8 \mathrm{~Hz}, J_{3,4}=1.7 \mathrm{~Hz}, \mathrm{H}-3\right), 3.33(1 \mathrm{H}$, dd, $\mathrm{H}-2$ ). Found: $\mathrm{C}, 63.72 ; \mathrm{H}, 5.32 \%$. Calcd for $\mathrm{C}_{14} \mathrm{H}_{14} \mathrm{O}_{5}$ : C, $64.11 ; \mathrm{H}, 5.38 \%$.

27: Syrup; $[\alpha]_{\mathrm{D}}^{25}+119.7^{\circ}(c \quad 0.7)$; IR $1722(\mathrm{C}=\mathrm{O})$; ${ }^{1} \mathrm{HNMR} \quad \delta=8.08-7.35(5 \mathrm{H} \times 2, \mathrm{~m}, \mathrm{Ph} \times 2), 5.23(1 \mathrm{H}, \mathrm{d}$, $\left.J_{4,5}=9.8 \mathrm{~Hz}, J_{4,3}=0 \mathrm{~Hz}, \mathrm{H}-4\right), 5.00\left(1 \mathrm{H}, \mathrm{s}, J_{1,2}=0 \mathrm{~Hz}, \mathrm{H}-1\right)$, $4.52\left(1 \mathrm{H}\right.$, dd, $\left.J_{6,5}=2.9 \mathrm{~Hz}, J_{6,6^{\prime}}=11.7 \mathrm{~Hz}, \mathrm{H}-6\right), 4.37(1 \mathrm{H}$, dd, $\left.J_{6^{\prime}, 5}=6.1 \mathrm{~Hz}, \mathrm{H}-6^{\prime}\right), 4.22(1 \mathrm{H}$, ddd, H-5), $3.52(3 \mathrm{H}, \mathrm{s}$, $\mathrm{OMe}), 3.40\left(1 \mathrm{H}, \mathrm{d}, J_{3,2}=3.4 \mathrm{~Hz}, \mathrm{H}-3\right), 3.17(1 \mathrm{H}, \mathrm{d}, \mathrm{H}-2)$. Found: C, $65.35 ; \mathrm{H}, 5.18 \%$. Calcd for $\mathrm{C}_{21} \mathrm{H}_{20} \mathrm{O}_{7}$ : C, 65.61 ; $\mathrm{H}, 5.24 \%$.

Conditions (B): After a mixture of 6-bromo derivative 25 (200 mg, $0.58 \mathrm{mmol}$ ), NaI (473 mg, $3.16 \mathrm{mmol}$ ), Bu ${ }_{4} \mathrm{NI}$ (108 $\mathrm{mg}, 0.29 \mathrm{mmol}$ ), and molecular sieves $4 \mathrm{~A}$ (10 pieces) in dry DMSO $\left(4.0 \mathrm{~cm}^{3}\right)$ was stirred at $80^{\circ} \mathrm{C}$ for $4 \mathrm{~h}$, DBU $(106$ $\mathrm{mg}, 0.70 \mathrm{mmol}$ ) was added and stirred for an additional 3.5 $\mathrm{h}$ at $80^{\circ} \mathrm{C}$. The reaction mixture was worked up in a similar manner as mentioned above to give the desired product 26 and by-product 27 in 52 and $6 \%$ yields, respectively.

Methyl 2,3-Anhydro-4- $O$-benzoyl- $\alpha$-D- ribo-hex5-enopyranoside (29), Methyl 2,3-Anhydro-4, 6di- $O$-benzoyl- $\alpha$-D-allopyranoside (30), and Methyl 2,3-Anhydro-6- $O$-benzoyl- $\alpha$-D-allopyranoside (31). Conditions (A): A mixture of methyl 2,3-anhydro-4$O$-benzoyl-6-bromo-6-deoxy- $\alpha$-D-allopyranoside 28 (204 mg, $0.59 \mathrm{mmol})$ and DBU $(108 \mathrm{mg}, 0.71 \mathrm{mmol})$ in DMSO (4.7 $\mathrm{cm}^{3}$ ) was stirred at $80^{\circ} \mathrm{C}$ for $24 \mathrm{~h}$ under argon. A similar work up of the reaction mixture as mentioned above, and then purification on a column of silica gel (hexane-ethyl acetate $=2: 1$, gave a mixture of hexosene 29, 4,6-di- $O$ benzoyl derivative 30 , and 6- $O$-benzoyl derivative 31 , which were separated by recrystallization (ethanol-hexane) and on a column of silica gel. The yields of products $29, \mathbf{3 0}$, and 31 were 13,18 , and $7 \%$, respectively.

29: Syrup; $[\alpha]_{D}^{25}+255.1^{\circ}$ (c 1.0); IR $1725(\mathrm{C}=\mathrm{O}), 1665$ $(\mathrm{C}=\mathrm{C}) ;{ }^{1} \mathrm{H}$ NMR $\delta=8.17-7.34(5 \mathrm{H}, \mathrm{m}, \mathrm{Ph}), 5.93(1 \mathrm{H}$, ddd, $\left.J_{4,3}=1.7 \mathrm{~Hz}, J_{4,6}=2.0 \mathrm{~Hz}, J_{4,6^{\prime}}=2.0 \mathrm{~Hz}, \mathrm{H}-4\right), 5.10(1 \mathrm{H}, \mathrm{d}$, $\left.J_{1,2}=2.4 \mathrm{~Hz}, \mathrm{H}-1\right), 4.85\left(1 \mathrm{H}, \mathrm{dd}, J_{6,6^{\prime}}=1.7 \mathrm{~Hz}, \mathrm{H}-6\right), 4.77$ $\left(1 \mathrm{H}, \mathrm{dd}, \mathrm{H}-6^{\prime}\right), 3.63\left(1 \mathrm{H}, \mathrm{dd}, J_{3,2}=3.4 \mathrm{~Hz}, \mathrm{H}-3\right), 3.60(1 \mathrm{H}$, dd, H-2), $3.59(3 \mathrm{H}, \mathrm{s}, \mathrm{OMe})$. Found: $\mathrm{C}, 64.04 ; \mathrm{H}, 5.37 \%$ Calcd for $\mathrm{C}_{14} \mathrm{H}_{14} \mathrm{O}_{5}: \mathrm{C}, 64.12 ; \mathrm{H}, 5.38 \%$.

30: $\quad$ Mp $123-124^{\circ} \mathrm{C}$ (ethanol-hexane); $[\alpha]_{\mathrm{D}}^{25}+177.2^{\circ}$ (c 0.7); IR $1722(\mathrm{C}=\mathrm{O}) ;{ }^{1} \mathrm{H}$ NMR $\delta=8.08-7.38(5 \mathrm{H} \times 2, \mathrm{~m}$, $\mathrm{Ph} \times 2), 5.45\left(1 \mathrm{H}, \mathrm{dd}, J_{4,3}=1.7 \mathrm{~Hz}, J_{4,5}=9.5 \mathrm{~Hz}, \mathrm{H}-4\right), 5.00$ $\left(1 \mathrm{H}, \mathrm{d}, J_{1,2}=3.2 \mathrm{~Hz}, \mathrm{H}-1\right), 4.56\left(1 \mathrm{H}, \mathrm{dd}, J_{6,5}=4.4 \mathrm{~Hz}, J_{6.6^{\prime}}=\right.$ $13.7 \mathrm{~Hz}, \mathrm{H}-6), 4.42\left(1 \mathrm{H}\right.$, ddd, $\left.J_{5,6^{\prime}}=1.7 \mathrm{~Hz}, \mathrm{H}-5\right), 4.39(1 \mathrm{H}$, dd, H-6 $), 3.73\left(1 \mathrm{H}, \mathrm{dd}, J_{3,2}=4.2 \mathrm{~Hz}, \mathrm{H}-3\right), 3.62(1 \mathrm{H}, \mathrm{dd}, \mathrm{H}-$ 2), $3.51(3 \mathrm{H}, \mathrm{s}, \mathrm{OMe})$. Found: $\mathrm{C}, 65.18 ; \mathrm{H}, 5.27 \%$. Calcd for $\mathrm{C}_{21} \mathrm{H}_{20} \mathrm{O}_{7}$ : C, 65.62; $\mathrm{H}, 5.24 \%$.

31: $\quad \mathrm{Mp} 142-143^{\circ} \mathrm{C}$ (ethanol-hexane); $[\alpha]_{\mathrm{D}}^{25}+114.6^{\circ}$ (c 0.3); IR $3490(\mathrm{OH}), 1698(\mathrm{C}=\mathrm{O}) ;{ }^{1} \mathrm{H}$ NMR $\delta=8.08-7.36$ $(5 \mathrm{H}, \mathrm{m}, \mathrm{Ph}), 4.92\left(1 \mathrm{H}, \mathrm{d}, J_{1,2}=3.2 \mathrm{~Hz}, \mathrm{H}-1\right), 4.63(1 \mathrm{H}, \mathrm{dd}$, $\left.J_{6,5}=4.6 \mathrm{~Hz}, J_{6,6^{\prime}}=12.2 \mathrm{~Hz}, \mathrm{H}-6\right), 4.54\left(1 \mathrm{H}, \mathrm{dd}, J_{6^{\prime}, 5}=2.3\right.$ $\left.\mathrm{Hz}, \mathrm{H}-6^{\prime}\right), 3.96\left(1 \mathrm{H}\right.$, ddd, $\left.J_{5,4}=4.3 \mathrm{~Hz}, \mathrm{H}-5\right), 3.94(1 \mathrm{H}$, dd, $\left.J_{4,3}=2.3 \mathrm{~Hz}, \mathrm{H}-4\right), 3.58\left(1 \mathrm{H}, \mathrm{dd}, J_{2,3}=4.2 \mathrm{~Hz}, \mathrm{H}-2\right), 3.52(1 \mathrm{H}$ dd, $\mathrm{H}-3), 3.46(3 \mathrm{H}, \mathrm{s}, \mathrm{OMe}), 2.62(1 \mathrm{H}, \mathrm{bs}, \mathrm{OH})$. Found: $\mathrm{C}$, $59.64 ; \mathrm{H}, 5.90 \%$. Calcd for $\mathrm{C}_{14} \mathrm{H}_{16} \mathrm{O}_{6}$ : C, $59.99 ; \mathrm{H}, 5.75 \%$.

Conditions (B): After a mixture of 6-bromo derivative $28(234 \mathrm{mg}, 0.68 \mathrm{mmol}), \mathrm{NaI}(511 \mathrm{mg}, 3.41 \mathrm{mmol}), \mathrm{Bu}_{4} \mathrm{NI}$ (126 mg, $0.34 \mathrm{mmol}$ ), and molecular sieves $4 \mathrm{~A}$ (10 pieces) in DMSO $\left(4.7 \mathrm{~cm}^{3}\right)$ was stirred at $80^{\circ} \mathrm{C}$ for $3.5 \mathrm{~h}$ under argon, DBU (125 mg, $0.82 \mathrm{mmol}$ ) was added and stirred for an additional $16 \mathrm{~h}$. A similar work up of the reaction mixture as conditions (A) gave the corresponding products 29,30 , and 31 in 16,20 , and $11 \%$ yields, respectively.

Elimination Reactions of Methyl-Branched Hexopyranoside Series $(32,34,36,38,40,42$, and 44$)$ under the Conditions (B). Methyl 2,3-Di-O-acetyl-4$O$-benzoyl-2- $C$-methyl- $\alpha$-D-xylo-hex-5-enopyranoside (33). After a mixture of methyl 2,3-di- $O$-acetyl-4- $O$-benzoyl-6-bromo-6-deoxy-2- $C$-methyl- $\alpha$-D-glucopyranoside 32 $(500 \mathrm{mg}, 1.09 \mathrm{mmol}), \mathrm{NaI}(950 \mathrm{mg}, 6.34 \mathrm{mmol})$, and $\mathrm{Bu}_{4} \mathrm{NI}$ $(230 \mathrm{mg}, 0.62 \mathrm{mmol})$ in DMSO $\left(50 \mathrm{~cm}^{3}\right)$ was stirred under argon in the presence of molecular sieves $4 \mathrm{~A}$ (20 pieces) at $80^{\circ} \mathrm{C}$ for $8 \mathrm{~h}, \mathrm{DBU}(970 \mathrm{mg}, 6.38 \mathrm{mmol})$ was added and kept until the disappearance of the 6-iodo derivative (for $12 \mathrm{~h}$ ). The reaction mixture was purified directly on a column of silica gel (Kieselgel 60, ethanol-hexane $=1: 2$ ) and recrystallized to give the corresponding enopyranoside $\mathbf{3 3}$ in $\mathbf{7 4 \%}$ yield.

33: $\quad$ Mp 106- $107^{\circ} \mathrm{C}$ (ethanol-hexane); $[\alpha]_{\mathrm{D}}^{25}+53.0^{\circ}(c$ 0.2); IR 1770 and $1750(\mathrm{C}=\mathrm{O}), 1680(\mathrm{C}=\mathrm{C}) ;{ }^{1} \mathrm{H} N M R \quad \delta=$ $8.10-7.43(5 \mathrm{H}, \mathrm{m}, \mathrm{Ph}), 5.72\left(1 \mathrm{H}, \mathrm{d}, J_{3,4}=10.2 \mathrm{~Hz}, \mathrm{H}-3\right)$, $5.64\left(1 \mathrm{H}\right.$, ddd, $\left.J_{4,6}=J_{4,6^{\prime}}=2.0 \mathrm{~Hz}, \mathrm{H}-4\right), 5.59(1 \mathrm{H}, \mathrm{s}, \mathrm{H}-$ 1), $4.77\left(1 \mathrm{H}, \mathrm{dd}, J_{6,6^{\prime}}=2.0 \mathrm{~Hz}, \mathrm{H}-6\right), 4.58\left(1 \mathrm{H}, \mathrm{dd}, \mathrm{H}-6^{\prime}\right)$, $3.45(3 \mathrm{H}, \mathrm{s}, \mathrm{OMe}), 2.01$ and $1.98(3 \mathrm{H} \times 2$, each $\mathrm{s}, \mathrm{OAc} \times 2)$, $1.72(3 \mathrm{H}, \mathrm{s}, \mathrm{C}-\mathrm{Me})$. Found: $\mathrm{C}, 60.03 ; \mathrm{H}, 5.65 \%$. Calcd for $\mathrm{C}_{19} \mathrm{H}_{22} \mathrm{O}_{8}$ : C, $60.31 ; \mathrm{H}, 5.86 \%$.

Methyl 2,3-Di- $O$-acetyl-4- $O$-benzoyl-2- $C$-methyl$\alpha$-D-lyxo-hex-5-enopyranoside (35). Methyl 2,3-di- $O$ acetyl-4- $O$-benzoyl-6-bromo-6-deoxy-2- $C$-methyl- $\alpha$-D-mannopyranoside 34 was treated in a similar manner as mentioned above to give the corresponding enopyranoside $\mathbf{3 5}$ in $78 \%$ yield.

35: Syrup; $[\alpha]_{\mathrm{D}}^{23}-20.3^{\circ}(c 0.2)$; IR 1760 and $1740(\mathrm{C}=0)$ $1670(\mathrm{C}=\mathrm{C}) ;{ }^{1} \mathrm{H}$ NMR $\delta=8.09-7.36(5 \mathrm{H}, \mathrm{m}, \mathrm{Ph}), 5.97(1 \mathrm{H}$, ddd, $\left.J_{4,3}=10.0 \mathrm{~Hz}, J_{4,6}=J_{4,6^{\prime}}=2.0 \mathrm{~Hz}, \mathrm{H}-4\right), 5.58(1 \mathrm{H}, \mathrm{d}, \mathrm{H}-$ 3), $5.57(1 \mathrm{H}, \mathrm{s}, \mathrm{H}-1), 4.77\left(1 \mathrm{H}, \mathrm{dd}, J_{6,6^{\prime}}=1.7 \mathrm{~Hz}, \mathrm{H}-6\right), 4.54$ $\left(1 \mathrm{H}, \mathrm{dd}, \mathrm{H}-6^{\prime}\right), 3.49(3 \mathrm{H}, \mathrm{s}, \mathrm{OMe}), 2.14$ and $1.99(3 \mathrm{H} \times 2$, each s, OAc $\times 2), 1.56(3 \mathrm{H}, \mathrm{s}, \mathrm{C}-\mathrm{Me})$. Found: $\mathrm{C}, 59.92 ; \mathrm{H}$, $5.73 \%$. Calcd for $\mathrm{C}_{19} \mathrm{H}_{22} \mathrm{O}_{8}: \mathrm{C}, 60.31 ; \mathrm{H}, 5.86 \%$. 
Methyl 4- $O$-Benzoyl-2,3-di- $O$-methyl-2- $C$-methyl$\alpha$-D-xylo-hex-5-enopyranoside (37). After a mixture of methyl 4-O-benzoyl-6-bromo-6-deoxy-2,3-di- $O$-methyl2 - $C$-methyl- $\alpha$-D-glucopyranoside $36(500 \mathrm{mg}, 1.24 \mathrm{mmol}$ ), $\mathrm{NaI}(1.12 \mathrm{~g}, 7.47 \mathrm{mmol})$, and $\mathrm{Bu}_{4} \mathrm{NI}(275 \mathrm{mg}, 0.74 \mathrm{mmol})$ in DMSO $\left(80 \mathrm{~cm}^{3}\right)$ was stirred under argon in the presence of molecular sieves $4 \mathrm{~A}$ (20 pieces) at $80^{\circ} \mathrm{C}$ for $8 \mathrm{~h}, \mathrm{DBU}$ (905 $\mathrm{mg}, 5.95 \mathrm{mmol}$ ) was added and kept at $80^{\circ} \mathrm{C}$ until the disappearance of the 6-iodo derivative (for $14 \mathrm{~h}$ ). A similar work up of the reaction mixture as mentioned above gave 37 in $86 \%$ yield.

37: $\quad$ Mp 99- $101^{\circ} \mathrm{C}$ (ethanol-hexane); $[\alpha]_{\mathrm{D}}^{25}+53.0^{\circ}(c$ 0.2); IR 1729 (C=O), $1680(\mathrm{C}=\mathrm{C}) ;{ }^{1} \mathrm{H}$ NMR $\delta=8.13-7.44$ $(5 \mathrm{H}, \mathrm{m}, \mathrm{Ph}), 5.62\left(1 \mathrm{H}, \mathrm{ddd}, J_{4,3}=9.5 \mathrm{~Hz}, J_{4,6}=J_{4,6^{\prime}}=2.2\right.$ $\mathrm{Hz}, \mathrm{H}-4), 4.70\left(1 \mathrm{H}, \mathrm{dd}, J_{6,6^{\prime}}=2.2 \mathrm{~Hz}, \mathrm{H}-6\right), 4.67(1 \mathrm{H}, \mathrm{s}, \mathrm{H}-1)$, $4.50\left(1 \mathrm{H}, \mathrm{dd}, \mathrm{H}-6^{\prime}\right), 3.82(1 \mathrm{H}, \mathrm{d}, \mathrm{H}-3), 3.513 .50$, and 3.38 $(3 \mathrm{H} \times 3$, each $\mathrm{s}, \mathrm{OMe} \times 3), 1.42(3 \mathrm{H}, \mathrm{s}, \mathrm{C}-\mathrm{Me})$. Found: $\mathrm{C}$, $63.49 ; \mathrm{H}, 7.03 \%$. Calcd for $\mathrm{C}_{17} \mathrm{H}_{22} \mathrm{O}_{6}$ : C, $63.34 ; \mathrm{H}, 6.88 \%$.

Methyl 4- $O$-Benzoyl-2,3-di- $O$-methyl-2- $C$-methyl- $\alpha$-D-lyxo-hex-5-enopyranoside (39). Methyl 4$O$-benzoyl-6-bromo-6-deoxy-2,3-di- $O$-methyl-2- $C$-methyl- $\alpha$ D-mannopyranoside $\mathbf{3 8}$ was treated in a similar manner as mentioned above to give the corresponding enopyranoside 39 in $75 \%$ yield.

39: Syrup; IR $1730(\mathrm{C}=\mathrm{O}), 1680(\mathrm{C}=\mathrm{C}) ;{ }^{1} \mathrm{H} N M R \quad \delta=$ $8.17-7.41(5 \mathrm{H}, \mathrm{m}, \mathrm{Ph}), 6.03\left(1 \mathrm{H}, \mathrm{ddd}, J_{4,3}=10.0 \mathrm{~Hz}, J_{4,6}=\right.$ $\left.J_{4,6^{\prime}}=2.2 \mathrm{~Hz}, \mathrm{H}-4\right), 4.67\left(1 \mathrm{H}, \mathrm{dd}, J_{6,6^{\prime}}=2.2 \mathrm{~Hz}, \mathrm{H}-6\right), 4.67$ $(1 \mathrm{H}, \mathrm{s}, \mathrm{H}-1), 4.46\left(1 \mathrm{H}, \mathrm{dd}, \mathrm{H}-6^{\prime}\right), 3.61(1 \mathrm{H}, \mathrm{d}, \mathrm{H}-3), 3.50$, 3.47 , and $3.42(3 \mathrm{H} \times 3$, each s, $\mathrm{OMe} \times 3), 1.37(3 \mathrm{H}, \mathrm{s}, \mathrm{CMe})$. Found: $\mathrm{C}, 63.52 ; \mathrm{H}, 7.05 \%$. Calcd for $\mathrm{C}_{17} \mathrm{H}_{22} \mathrm{O}_{6}$ : C, 63.34; $\mathrm{H}, 6.88 \%$.

Methyl 2,3-Di- $O$-acetyl-4- $O$-benzoyl-3- $C$-methyl$\alpha$-D-ribo-hex-5-enopyranoside (41). Methyl 2,3-di- $O$ acetyl-4- $O$-benzoyl-6-bromo-6-deoxy-3- $C$-methyl- $\alpha$-D-allopyranoside 40 was treated in a similar manner as in the case of compound 33 to give the corresponding enopyranoside $\mathbf{4 1}$ in $81 \%$ yield.

41: Syrup; $[\alpha]_{\mathrm{D}}^{23}+50.2^{\circ}(c 1.0)$; IR 1760 and $1740(\mathrm{C}=\mathrm{O})$, $1675(\mathrm{C}=\mathrm{C}) ;{ }^{1} \mathrm{H}$ NMR $\delta=8.31-7.17(5 \mathrm{H}, \mathrm{m}, \mathrm{Ph}), 5.95(1 \mathrm{H}$, $\mathrm{s}, \mathrm{H}-4), 5.51\left(1 \mathrm{H}, \mathrm{d}, J_{2,1}=2.4 \mathrm{~Hz}, \mathrm{H}-2\right), 5.00(1 \mathrm{H}, \mathrm{s}, \mathrm{H}-6)$, $4.97\left(1 \mathrm{H}, \mathrm{s}, \mathrm{H}-6^{\prime}\right), 4.81(1 \mathrm{H}, \mathrm{d}, \mathrm{H}-1), 3.62(3 \mathrm{H}, \mathrm{s}, \mathrm{OMe})$, 2.28 and $1.93(3 \mathrm{H} \times 2$, each s, OAc $\times 2), 1.77(3 \mathrm{H}, \mathrm{s}, \mathrm{C}-\mathrm{Me})$. Found: $\mathrm{C}, 60.04 ; \mathrm{H}, 5.98 \%$. Calcd for $\mathrm{C}_{19} \mathrm{H}_{22} \mathrm{O}_{8}$ : C, 60.31 ; $\mathrm{H}, 5.86 \%$.

Methyl 2,3-Di- $O$-acetyl-4- $O$-benzoyl- $\alpha$-D- $x y l o$-hex5-enopyranoside (43). Methyl 2,3-di- $O$-acetyl-4- $O$-benzoyl-6-bromo-6-deoxy-3- $C$-methyl- $\alpha$-D-glucopyranoside 42 was treated in a similar manner as in the case of compound 32 to give the corresponding enopyranoside $\mathbf{4 3}$ in $80 \%$ yield.

43: Syrup; $[\alpha]_{\mathrm{D}}^{25}+84.2^{\circ}(c 0.2)$; IR 1760 and $1740(\mathrm{C}=\mathrm{O})$, $1670(\mathrm{C}=\mathrm{C}) ;{ }^{1} \mathrm{H}$ NMR $\delta=8.14-7.26(5 \mathrm{H}, \mathrm{m}, \mathrm{Ph}), 6.52(1 \mathrm{H}$, dd, $\left.J_{4,6}=J_{4,6^{\prime}}=1.5 \mathrm{~Hz}, \mathrm{H}-4\right), 6.05\left(1 \mathrm{H}, \mathrm{d}, J_{2,1}=4.2 \mathrm{~Hz}, \mathrm{H}-\right.$ 2), $5.03(1 \mathrm{H}, \mathrm{d}, \mathrm{H}-1), 4.82\left(1 \mathrm{H}, \mathrm{dd}, J_{6,6^{\prime}}=1.5 \mathrm{~Hz}, \mathrm{H}-6\right), 4.76$ $\left(1 \mathrm{H}, \mathrm{dd}, \mathrm{H}-6^{\prime}\right), 3.62(3 \mathrm{H}, \mathrm{s}, \mathrm{OMe}), 2.28$ and $1.93(3 \mathrm{H} \times 2$, each s, OAc $\times 2), 1.77(3 \mathrm{H}, \mathrm{s}, \mathrm{C}-\mathrm{Me})$. Found: $\mathrm{C}, 60.53 ; \mathrm{H}$, $5.72 \%$. Calcd for $\mathrm{C}_{19} \mathrm{H}_{22} \mathrm{O}_{8}: \mathrm{C}, 60.31 ; \mathrm{H}, 5.86 \%$.

Methyl 2,3,4-Tri- $O$-methyl-4- $C$-methyl- $\alpha$-D-xylohex-5-enopyranoside (45). After a mixture of methyl 2,3,4-tri- $O$-methyl-4- $C$-methyl-6- $O$ - $p$-tolylsulfonyl- $\alpha$-Dglucopyranoside $44(600 \mathrm{mg}, 1.48 \mathrm{mmol})$, NaI $(1.10 \mathrm{~g}, 7.34$ $\mathrm{mmol})$, and $\mathrm{Bu}_{4} \mathrm{NI}(270 \mathrm{mg}, 0.73 \mathrm{mmol})$ in DMSO $\left(80 \mathrm{~cm}^{3}\right)$ was stirred under argon in the presence of molecular sieves
$4 \mathrm{~A}(20$ pieces $)$ at $120^{\circ} \mathrm{C}$ for $12 \mathrm{~h}, \mathrm{DBU}(1.10 \mathrm{~g}, 7.24 \mathrm{mmol})$ was added and kept at $120^{\circ} \mathrm{C}$ until the disappearance of 6iodo derivative on TLC (for $12 \mathrm{~h}$ ). A similar work up of the reaction mixture as in the case of compound 32 gave $\mathbf{4 5}$ in $91 \%$ yield.

45: Syrup; $[\alpha]_{\mathrm{D}}^{26}+119^{\circ}(c 1.4) ;$ IR $1680(\mathrm{C}=\mathrm{C}) ;{ }^{1} \mathrm{H}$ NMR $\delta=4.84\left(1 \mathrm{H}, \mathrm{d}, J_{1,2}=3.5 \mathrm{~Hz}, \mathrm{H}-1\right), 4.70\left(1 \mathrm{H}, \mathrm{d}, J_{6,6^{\prime}}=0.7\right.$ $\mathrm{Hz}, \mathrm{H}-6), 4.66\left(1 \mathrm{H}, \mathrm{d}, \mathrm{H}-6^{\prime}\right), 3.88\left(1 \mathrm{H}, \mathrm{d}, J_{3,2}=9.5 \mathrm{~Hz}, \mathrm{H}-3\right)$, $3.34(1 \mathrm{H}, \mathrm{dd}, \mathrm{H}-2), 3.63,3.54,3.46$, and $3.38(3 \mathrm{H} \times 4$, each $\mathrm{s}, \mathrm{OMe} \times 4), 1.37$ (3H, s, C-Me). Found: C, 56.93; H, 8.42\%. Calcd for $\mathrm{C}_{11} \mathrm{H}_{20} \mathrm{O}_{5}$ : C, $56.88 ; \mathrm{H}, 8.68 \%$.

Methyl 2,3,4-Tri- $O$-methyl-4- $C$-methyl-6- $O$-p-tolylsulfonyl- $\alpha$-D-glucopyranoside (44). MeI (1.3 equiv) was added dropwise to a mixture of methyl 2,3-di- $O$-methyl-4- $C$-methyl-6- $O$-triphenylmethyl- $\alpha$-D-glucopyranoside ${ }^{12)}$ and $\mathrm{NaH}$ (1.2 equiv) in $\mathrm{DMF}$ at $0^{\circ} \mathrm{C}$; the resulting mixture was kept at room temperature until the disappearance of the starting material. The reaction mixture was poured into a saturated $\mathrm{NH}_{4} \mathrm{Cl}$ solution, extracted with ethyl acetate, and evaporated to give syrupy crude methyl 2,3,4-tri- $O$-methyl-4$C$-methyl-6- $O$-triphenylmethyl- $\alpha$-D-glucopyranoside. A $70 \%$ acetic acid solution of the above mentioned 2,3,4-tri- $O$-methyl derivative was stirred at $60^{\circ} \mathrm{C}$ to give the corresponding 6 -hydroxy derivative. The yield was $82 \%$ (2 steps) after purification. A reaction of the above mentioned 6-hydroxy compound $(3.0 \mathrm{~g})$ with $p$-toluenesulfonyl chloride $(2.6 \mathrm{~g}, 1.2$ equiv) in pyridine was carried out for $12 \mathrm{~h}$. The reaction mixture was poured into water, extracted with ethyl acetate, and evaporated to give the 6-O-p-tolylsulfonyl derivative $\mathbf{4 4}$, which was recrystallized from ethanol-hexane. The yield was $80 \%$.

44: $\quad$ Mp $80-81^{\circ} \mathrm{C} ;[\alpha]_{\mathrm{D}}^{25}+94.2^{\circ}(c 1.2) ;{ }^{1} \mathrm{H}$ NMR $\delta=7.80$ and $7.30(4 \mathrm{H}, \mathrm{ABq}, \mathrm{Ph}), 4.74\left(1 \mathrm{H}, \mathrm{d}, J_{1,2}=3.9 \mathrm{~Hz}, \mathrm{H}-1\right)$, $4.30\left(1 \mathrm{H}, \mathrm{dd}, J_{5,6}=10.0 \mathrm{~Hz}, J_{5,6^{\prime}}=1.2 \mathrm{~Hz}, \mathrm{H}-5\right), 4.03(1 \mathrm{H}$, $\left.\mathrm{dd}, J_{6,6^{\prime}}=8.8 \mathrm{~Hz}, \mathrm{H}-6\right), 3.88\left(1 \mathrm{H}\right.$, dd, H- $\left.6^{\prime}\right), 3.14(1 \mathrm{H}$, dd, $\left.J_{2,3}=10.0 \mathrm{~Hz}, \mathrm{H}-2\right), 3.57,3.47,3.38$, and $3.32(3 \mathrm{H} \times 4$, each s, $\mathrm{OMe} \times 4), 2.42(3 \mathrm{H}, \mathrm{s}, \mathrm{Ph}-\mathrm{Me}), 1.08(3 \mathrm{H}, \mathrm{s}, \mathrm{C}-\mathrm{Me})$. Found: C, $53.46 ; \mathrm{H}, 6.96 \%$. Calcd for $\mathrm{C}_{18} \mathrm{H}_{28} \mathrm{O}_{8} \mathrm{~S}: \mathrm{C}, 53.45 ; \mathrm{H}$, $6.98 \%$

The authors thank Mr. Tetsutaro Igarashi for measuring the ${ }^{1} \mathrm{H} N M R$ spectra. The present work was partially supported by a Grant-in-Aid for Scientific Research from the Ministry of Education, Science and Culture.

\section{References}

1) S. Hanessian, Adv. Carbohydr. Chem., 21, 143 (1966); R. F. Butterworth and S. Hanessian, Adv. Carbohydr. Chem., 26, 279 (1971); K. Sato, S. Sakuma, K. Takahashi, and H. Hashimoto, Bull. Chem. Soc. Jpn., 65, 292 (1992).

2) R. J. Ferrier, J. Chem. Soc., Perkin Trans. 1, 1979, 1455; R. Brattner, R. J. Ferrier, and S. R. Hains, J. Chem. Soc., Perkin Trans. 1, 1985, and literatures cited therein.

3) T. M. Cheng, D. Horton, and W. Weckerle, Carbohydr. Res., 58, 139 (1977).

4) T. F. Gallagher and D. Horton, Carbohydr. Res., 116, 227 (1983).

5) F. Chretien, "3rd European Symposium on Carbohydrates," Grenoble, 1985, Abstr., p. 113. 
6) S. Hanessian and A. P. A. Staub, Carbohydr. Res., 16, 419 (1971).

7) K. Sato, N. Kubo, R. Takada, A. Aqeel, H. Hashimoto, and J. Yoshimura, Chem. Lett., 1988, 1703; K. Sato, S. Sakuma, Y. Nakamura, and H. Hashimoto, Chem. Lett., 1991, 17.

8) K. Sato, T. Igarashi, Y. Yanagisawa, N. Kawauchi, H. Hashimoto, and J. Yoshimura, Chem. Lett., 1988, 1699.

9) T. Yasumori, K. Sato, H. Hashimoto, and J. Yoshimura, Bull. Chem. Soc. Jpn., 57, 2538 (1984).

10) H. Kodama, Master Thesis, Tokyo Institute of Technology, 1979; 47: Mp 63-65 ${ }^{\circ} \mathrm{C}(\mathrm{EtOH}) ;{ }^{1} \mathrm{HNMR}$ $\delta=8.32-8.16$ and $7.66-7.27(5 \mathrm{H}, \mathrm{m}, \mathrm{Ph}), 5.17(1 \mathrm{H}$, dd, $\left.J_{1,2 \mathrm{a}}=9.0 \mathrm{~Hz}, J_{1,2 \mathrm{e}}=4.2 \mathrm{~Hz}, \mathrm{H}-1\right), 5.00(1 \mathrm{H}, \mathrm{d}, \mathrm{H}-4), 4.91$ $\left(1 \mathrm{H}, \mathrm{ddd}, J_{5,4}=3.0 \mathrm{~Hz}, \mathrm{H}-5\right), 4.04\left(1 \mathrm{H}, \mathrm{dd}, J_{6,5}=2.8, J_{6,6^{\prime}}=\right.$ $10.0 \mathrm{~Hz}, \mathrm{H}-6), 3.49$ (3H, s, OMe), $2.30(1 \mathrm{H}, \mathrm{dd}, \mathrm{H}-2 \mathrm{a}), 1.95$ $\left(1 \mathrm{H}, \mathrm{dd}, J_{2 \mathrm{e}, 2 \mathrm{a}}=12.5 \mathrm{~Hz}, \mathrm{H}-2 \mathrm{e}\right), 1.39(3 \mathrm{H}, \mathrm{s}, \mathrm{C}-\mathrm{Me})$.

11) M. Matsuzawa, Master Thesis, Tokyo Institute of Technology, 1977; 49: Mp $169-174^{\circ} \mathrm{C} ;[\alpha]_{\mathrm{D}}^{22}-111.3^{\circ}(c$ 1.0); IR $1720(\mathrm{C}=\mathrm{O})$ and 1622 (amido $\mathrm{C}=\mathrm{O}) ;{ }^{1} \mathrm{H} N \mathrm{NR} \delta=$ $8.30-7.25(5 \mathrm{H}, \mathrm{m}, \mathrm{Ph}), 4.74-4.62(3 \mathrm{H}, \mathrm{m}, \mathrm{H}-1, \mathrm{H}-4$, and $\mathrm{H}-5), 3.74\left(2 \mathrm{H}, \mathrm{d}, \mathrm{J}_{5,6}=1.0 \mathrm{~Hz}, \mathrm{H}-6\right.$ and $\left.\mathrm{H}-6^{\prime}\right), 3.51(3 \mathrm{H}, \mathrm{s}$, $\mathrm{OMe}), 2.51\left(1 \mathrm{H}, \mathrm{dd}, J_{2 \mathrm{a}, 1}=10.0 \mathrm{~Hz}, J_{2 \mathrm{a}, 2 \mathrm{e}}=13.0 \mathrm{~Hz}, \mathrm{H}-2 \mathrm{a}\right)$, $2.12(3 \mathrm{H}, \mathrm{s}, \mathrm{NAc}), 1.98\left(1 \mathrm{H}, \mathrm{dd}, J_{2 \mathrm{e}, 1}=4.0 \mathrm{~Hz}, \mathrm{H}-2 \mathrm{e}\right), 1.68$ $(3 \mathrm{H}, \mathrm{s}, \mathrm{C}-\mathrm{Me})$. Found: $\mathrm{C}, 63.93 ; \mathrm{H}, 6.63 ; \mathrm{N}, 4.39 \%$. Calcd for $\mathrm{C}_{17} \mathrm{H}_{21} \mathrm{O}_{5} \mathrm{~N}$ : C, $63.94 ; \mathrm{H}, 6.49 ; \mathrm{N}, 4.16 \%$.

12) M. Miljkovic, M. Gligorijevic, T. Satoh, and D. Miljkovic, J. Org. Chem., 39, 1379 (1974). 